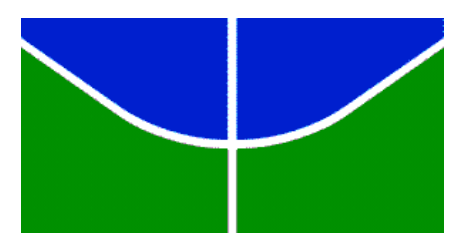

UNIVERSIDADE DE BRASÍLIA - UnB

Instituto de Ciências Biológicas

Instituto de Física

Instituto de Química

Faculdade UnB Planaltina

Programa de Pós-Graduação em Ensino de Ciências

Mestrado Profissional em Ensino de Ciências

\title{
EDUCAÇÃO SEXUAL E A FORMAÇÃO DE PROFESSORES: UMA PROPOSTA PARA A FORMAÇÃO INICIAL DOS LICENCIANDOS EM CIÊNCIAS NATURAIS (FUP)
}

\author{
ANDREZZA ROMENIA LIMA DE ABREU
}

Brasília, DF

Março/2017 


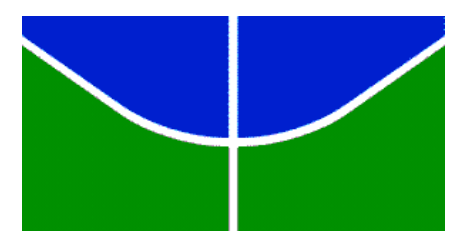

UNIVERSIDADE DE BRASÍLIA - UnB

Instituto de Ciências Biológicas

Instituto de Física

Instituto de Química

Faculdade UnB Planaltina

Programa de Pós-Graduação em Ensino de Ciências

Mestrado Profissional em Ensino de Ciências

\section{EDUCAÇÃO SEXUAL E A FORMAÇÃO DE PROFESSORES: UMA PROPOSTA PARA A FORMAÇÃO INICIAL DOS LICENCIANDOS EM CIÊNCIAS NATURAIS (FUP)}

ANDREZZA ROMENIA LIMA DE ABREU

Dissertação realizada sob orientação da Prof. ${ }^{a}$ Dr. $^{a}$ Alice Melo Ribeiro e coorientação da Prof. ${ }^{a}$ Dr. $^{a}$ Maria de Lourdes Lazzari de Freitas e apresentada à banca examinadora como critério parcial à obtenção do Título de Mestre pelo Programa de Pós-Graduação em Ensino de Ciências da Universidade de Brasília. 


\section{FICHA CATALOGRÁFICA}

\section{Abreu, Andrezza Romênia Lima de}

Educação Sexual e a Formação de Professores: Uma Proposta para a Formação Inicial dos Licenciandos em Ciências Naturais (FUP). Andrezza Romênia Lima de Abreu. Brasília, Programa de Pós Graduação em Ensino de Ciências (PPGEC) - Universidade de Brasília, 2017.

$63 \mathrm{p}$.

Dissertação de Mestrado - Universidade de Brasília, PPGEC.

Área de Concentração: Ensino de Ciências.

1. Sexualidade. 2. Educação Sexual. 3. Formação de Professores. 4. Ciências Naturais. I. Título. 


\section{FOLHA DE APROVAÇÃ̃o}

Andrezza Romênia Lima de Abreu

\section{"EDUCAÇÃO SEXUAL E AFORMAÇÃO DE PROFESSORES: UMA PROPOSTA PARA FORMAÇÃO INICIAL DOS LICENCIANDOS EM CIENCIAS NATURAIS (FUP)"}

Dissertação apresentada à banca examinadora como requisito parcial à obtenção do Título de Mestre em Ensino de Ciências pelo Programa de Pós- Graduação em Ensino de Ciências (PPGEC) da Universidade de Brasília (UnB).

Aprovada em 3 de março de 2017.

\section{BANCA EXAMINADORA}

Prof. ${ }^{a}$ Dra. Alice Melo Ribeiro - IB/UnB (Presidente)

Prof. ${ }^{a}$ Dra. Cynthia Bisinoto Evangelista de Oliveira - FUP/UnB

(Membro Titular)

Prof. ${ }^{a}$ Dra. Olgamir Amancia Ferreira - FUP/UnB

(Membro Titular)

Prof. ${ }^{a}$ Dra. Jeane Cristina Gomes Rotta - FUP/UnB

(Membro Suplente) 
Dedico este trabalho ao meu avô Severino; à minha querida mãe Aparecida, minha inspiração; ao meu amado sobrinho Murilo, anjo que ilumina a minha vida. 


\section{AGRADECIMENTOS}

Agradeço primeiramente a Deus pela vida e por tudo que ele tem me proporcionado.

À minha família, à minha mãe Aparecida, aos meus irmãos Amanda, Anderson e Anneska, por todo carinho e compreensão.

À minha orientadora Dra. Alice Melo Ribeiro e à co-orientadora Dra. Maria de Lourdes Lazzari de Freitas por todo apoio, carinho e paciência nesta caminhada.

Aos amigos que torceram, apoiaram-me, incentivaram e ofereceram ouvido, orações, opiniões, paciência, entre outras coisas. Aos amigos que conhece no PPGEC, aprende muito com vocês. A minha amiga Jessica Laís, pela parceria e apoio nessa caminhada.

À Samara Anjos, Regina Célia e ao Diego Jácome, que contribuíram e colaboraram brilhantemente com este trabalho.

As professoras Juliana Caixeta e Olgamir Amâncio pelas contribuições na defesa do projeto.

As professoras Cynthia Bisinoto, Olgamir Amâncio e Jeane Rota, por aceitarem compor a banca de defesa dessa dissertação.

À Anete querida professora e amiga, obrigada pelo apoio e carinho.

À Altemar pela ajuda especial na correção deste trabalho.

Aos professores do PPGEC, pela excelente formação que nos proporcionam.

À secretária do PPGEC por todo apoio e solicitações sempre atendidas.

À coordenação e à secretaria da FUP, que me acolheram.

À FAPDF pelo apoio a pesquisa.

Aos meus queridos alunos, que tornaram este trabalho possível, e por todo comprometimento nas aulas.

Agradeço a todos que de forma direta ou indireta colaboraram com este trabalho. 
"Já que não tenho o dom de modificar uma pessoa, vou modificar aquilo que eu posso: o meu jeito de olhar para ela" Pe. Fábio de Melo 


\section{RESUMO}

Temáticas ligadas à sexualidade fazem parte do cotidiano dos estudantes, seja na música, na mídia, em livros ou em conversas com os colegas. Omitir e/ou ignorar questões ligadas à sexualidade não são atitudes adequadas a serem tomadas quando se tem a missão de formar cidadãos críticos e comprometidos com suas escolhas. A Educação Sexual vem sendo reconhecida, pela maioria dos professores, como necessária e importante no processo formativo dos alunos. Os Parâmetros Curriculares Nacionais (PCN) propõem que os temas sobre sexualidade sejam apresentados por meio da transversalidade dos conteúdos na escola. Portanto, o objetivo da pesquisa é a elaboração de uma proposta de formação inicial para os licenciandos em Ciências Naturais, por meio de uma disciplina sobre a Educação Sexual como proposição, fundamentada na prática reflexiva. Os dados obtidos em sala de aula foram analisados de forma qualitativa. Os resultados indicaram que é de suma importância a Educação Sexual na formação inicial dos licenciandos para melhor desempenho dos futuros professores em sala de aula. Podemos perceber que mesmo com muitos preconceitos e tabus relacionados à sexualidade, é possível trabalhar a Educação Sexual em sala de aula por meio de atividades que são viáveis e podem favorecer o ensino da temática como os recursos didáticos, a sensibilização dos alunos e a prática reflexiva. .

Palavras-chave: Sexualidade. Educação Sexual. Formação de Professores. Ciências Naturais. 


\begin{abstract}
Themes related to sexuality are part of students' daily lives, whatever in music, media, books or in conversations with colleagues. Omitting or ignoring sexual issues are not appropriate attitudes in order to train citizens who are critical and committed to your choices. Whence, Sexual Education has been recognized by most teachers as necessary and important in the formative process of students. The National Curriculum Parameters (NCP) for Basic Education in Brazil propose that topics on sexuality be presented as transversal contents in the school. Therefore, the research proposal focuses on initial training over sexuality for Natural Science graduates, discussed during the Sexual Education discipline, and based on reflective practice. The data analyzed in a qualitative way confirm how important the discipline for the performance of the future teachers is. Despite of many prejudices and sexual taboos it is possible to work Sexual Education in the classrooms by means of feasible activities that can favor the teaching of the subject, such as didactic resources, student awareness and reflective practice.
\end{abstract}

Keywords: Sexuality. Sexual Education. Teacher Training. Natural Sciences. 


\section{LISTA DE ABREVIATURAS E SIGLAS}

AVA Ambiente Virtual de Aprendizagem

AIDS Síndrome da Inumo Deficiência Adquirida

CID Classificação Internacional das Doenças

CN Ciências Naturais

DF Distrito Federal

DST Doenças Sexualmente Transmissíveis

FUP Faculdade UnB de Planaltina

GDE Gênero e Diversidade na Escola

IES Instituição de Ensino Superior

MEC Ministério da Educação

OMS Organização Mundial de Saúde

PCN Parâmetros Curriculares Nacionais

PPGEC Programa de Pós-Graduação em Ensino de Ciências

PPP Projeto Político Pedagógico

SEF Secretaria de Educação Fundamental

TCLE Termo de Consentimento Livre Esclarecido

UNB Universidade de Brasília 


\section{SUMÁRIO}

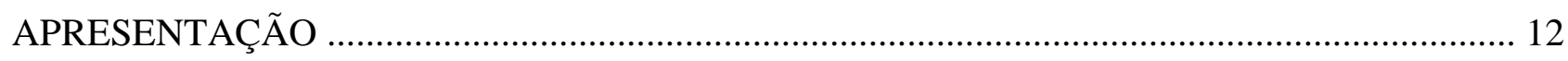

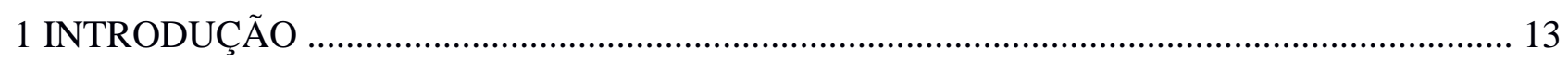

2 SEXUALIDADE, EDUCAÇÃO SEXUAL E A ESCOLA …................................................ 15

3 EDUCAÇÃO SEXUAL E FORMAÇÃO DE PROFESSORES …............................................. 18

4 A LICENCIATURA EM CIÊNCIAS NATURAIS NA FUP ................................................. 20

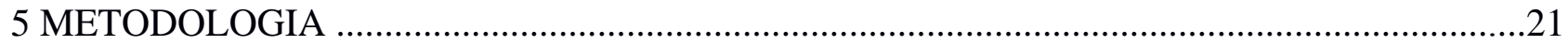

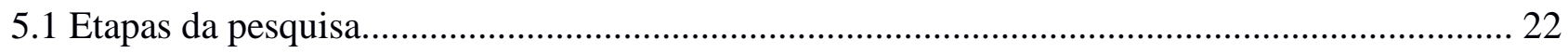

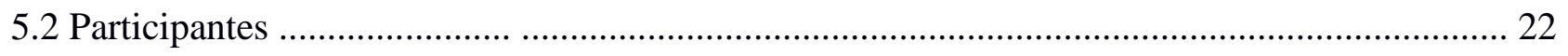

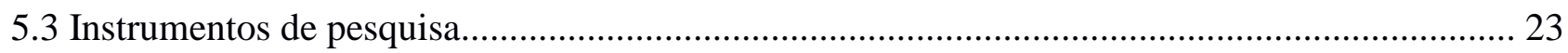

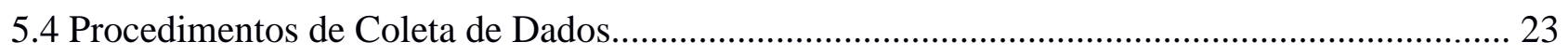

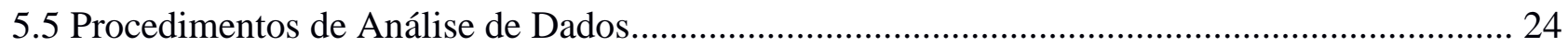

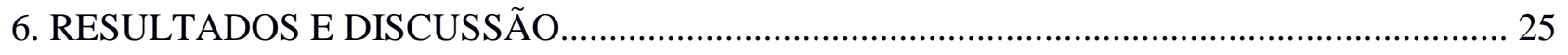

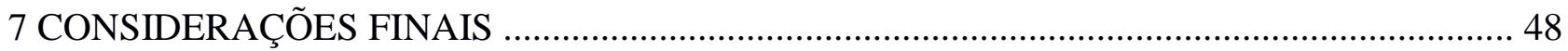

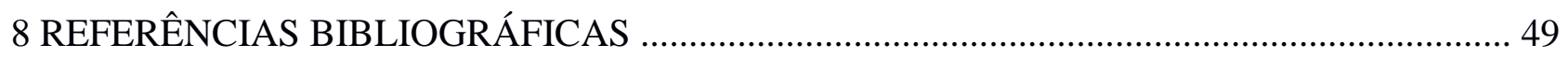

APÊNDICE A - Termo de Consentimento Livre e Esclarecido.................................................... 53

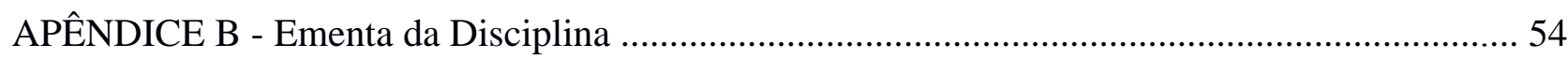

APÊNDICE C - Proposição Didática (Educação Sexual). ........................................................ 56 


\section{APRESENTAÇÃO}

Sempre gostei muito da disciplina de "Ciências" durante o ensino fundamental. Talvez essa afinidade com as Ciências Naturais tenha surgido graças a minha excelente professora da $5^{\mathrm{a}}$ série/ $6^{\circ}$ ano, que, com suas aulas, sempre despertou em mim muito interesse e curiosidade por essa área que nos explica um pouco sobre tudo o que existe, digo, um pouco, porque o universo passa a todo tempo por inúmeras transformações, inovações e descobertas. Em 2009, tive o prazer de ingressar na Universidade de Brasília (UnB) no curso de Licenciatura em Ciências Naturais $(\mathrm{CN})$ noturno, no campus de Planaltina, no Distrito Federal (DF). Dentre as muitas experiências vividas durante a graduação, dois projetos, em especial, foram muito importantes para minha formação. O primeiro iniciei no terceiro semestre de curso, quando participei do "Prodocência", que se constituía numa parceria entre as escolas públicas do DF e alguns cursos de licenciaturas da Universidade de Brasília, entre eles, o curso de Ciências Naturais da Faculdade UnB Planaltina (FUP). Este curso proporcionou-me uma vivência com o ambiente escolar, que fez toda diferença durante os estágios, pois estava mais confiante e segura em sala de aula.

A segunda experiência surgiu durante o quarto semestre, mais especificamente quando cursei uma disciplina obrigatória do curso chamada Didática das Ciências, na qual trabalhei pela primeira vez no ensino fundamental com a temática "Sexualidade", em forma de minicurso. Desde então, tenho percebido a importância da reflexão e discussão dessa temática. A experiência foi tão positiva que continuei trabalhando em muitas escolas públicas, após ter cursado a disciplina, com minicursos de sexualidade, nos projetos de extensão "Projetos Interdisciplinares em Ensino de Ciências - A FUP vai às escolas públicas" e "Ensinando Ciências por meio de projetos".

Ao concluir a graduação, sempre visei dar continuidade à minha formação profissional, foi então que surgiu uma oportunidade de desenvolvimento e aprendizagem pessoal e profissional no Programa de Pós-Graduação em Ensino de Ciências (PPGEC) da UnB. Ingressei no PPGEC em 2015 e participei de disciplinas que fortaleceram e aprimoraram meus conhecimentos. Com a minha trajetória acadêmica, senti a necessidade de trabalhar o tema Educação Sexual na perspectiva de colaborar com a formação inicial dos licenciandos em $\mathrm{CN}$, proporcionando uma reflexão sobre a temática e buscando possibilidades e estratégias para o ensino em sala de aula. Visto que estes licenciandos serão futuros professores e na sua prática docente, vivenciarão situações e desafios com temas considerados polêmicos, tabus, como por exemplo, a sexualidade. Essa necessidade/vontade de trabalhar na formação inicial aflorou em mim, porque durante minha graduação não cursei nenhuma disciplina que trabalhasse o tema, somente no projeto eu pude ter contato mais direto com a temática, durante a disciplina de Didática foi uma escolha minha 
trabalhar com a temática.

\section{INTRODUÇÃO}

A escola é um espaço de socialização, é nela que as crianças e os adolescentes passam a maior parte do tempo, estabelecendo suas primeiras relações afetivas fora do convívio familiar, sejam elas em vínculos de amizade ou em pares.

Nesse sentido, Ramiro e Matos (2008, p.2) destacam que "a escola é lugar privilegiado para realização da educação sexual formal e articulada", pois crianças e adolescentes permanecem um tempo significativo na escola. Werebe (1981 apud FIGUEIRO, p. 84, 1996) define os dois tipos de Educação Sexual:

A educação sexual informal, processo global, não intencional, que engloba toda a ação exercida sobre o indivíduo, no seu cotidiano, desde o nascimento, com repercussão direta ou indireta sobre sua vida sexual; a educação sexual formal, deliberada, institucionalizada, feita dentro ou fora da escola.

Silva e Santos (2011) verificaram em seus estudos que existe uma lacuna na formação inicial docente, pois no currículo regular do curso de licenciatura não existe um espaço para a reflexão com os/as futuros/as professores/as sobre a sexualidade, dificultando um trabalho teórico e prático cientificamente fundamentado.

A Educação Sexual vem sendo reconhecida, pela maioria dos professores, como necessária e importante no processo formativo dos alunos. Muitos deles "se preocupam e se sentem, em vários momentos, inseguros e até temerosos", diante desta tarefa (FIGUEIRÓ, 2009, p. 141). Nesse sentido a autora salienta:

a preocupação e o interesse em proporcionar às pessoas, em especial às crianças e aos jovens, uma Educação Sexual que os torne capazes de viver a sexualidade com liberdade e em plenitude, não é exclusiva de educadores e pensadores de nosso século, embora seja nesse período, que essa preocupação e interesse emergiram com mais vigor e determinação (FIGUEIRÓ, 1996, p. 83).

Os Parâmetros Curriculares Nacionais (PCN) propõem que os temas sobre sexualidade sejam apresentados por meio da transversalidade dos conteúdos na escola. O conhecimento do corpo transcende sua dimensão biológica. No corpo estão inscritas a história de vida, a cultura, os desejos e as aprendizagens do indivíduo (BRASIL, 1998, p. 51). No entanto, essa abordagem tem apresentado difícil implementação, como descreve Oliveira (2009, p.181):

$\mathrm{Na}$ prática, o tema Orientação Sexual tem se demonstrado de difícil implementação, aparecendo muito mais como um ideal na narrativa dos educadores, como aquilo que deveria ser feito, ou do que de fato acontece no dia-adia da escola. [...] Há necessidade urgente de cursos de formação continuada de Professores para a orientação sexual na escola. Esta formação requer formadores e formandos motivados, livres de preconceitos e com um firme desejo de auxiliar 
indivíduos a compreenderem que a sexualidade e todos os aspectos a ela relacionados são indicadores de todo um equilíbrio que o organismo busca. Encarar e viver a sexualidade como uma das coisas mais bonitas da vida exige muita coragem de todos nós.

Como ressalta a autora, é um trabalho desafiador, visto que estamos inseridos em uma sociedade conservadora em que falar de sexualidade ainda é tabu. Porém, tratando-se da formação de professores, é de suma importância discutirmos tal temática. Portanto, o problema da pesquisa surge da prática e observação da própria pesquisadora, sendo o objetivo a elaboração de proposição e desenvolvimento de uma disciplina sobre Educação Sexual com estudantes do Curso de Ciências Naturais da Faculdade UnB Planaltina. Para alcançar o objetivo proposto, definiram-se os seguintes objetivos específicos:

- Propiciar, entre os licenciandos do curso de Ciências Naturais, um espaço aberto para reflexão, discussão e aprendizagem sobre a Educação Sexual.

- Apresentar, aos estudantes da Licenciatura em Ciências Naturais, recursos didáticos com potencial de uso em sua prática profissional na educação básica.

- Construir uma proposta didática em Educação Sexual para o contexto da Licenciatura em Ciências Naturais da FUP.

Por meio deste trabalho algumas considerações são apresentadas sobre a Sexualidade, Educação Sexual e a Escola. Em seguida, traz contribuições sobre a Educação Sexual e a Formação de Professores baseadas, principalmente, nas obras de Figueiró (1995, 1996, 2009). Por fim, traz uma breve apresentação do Curso de Ciências Naturais da FUP. Na sequência, a metodologia, os resultados, discussões e considerações finais. 


\section{SEXUALIDADE, EDUCAÇÃO SEXUAL E A ESCOLA}

A história da sexualidade, segundo Foucault (1988), começa a ser discutida cientificamente por profissionais da medicina durante o século XIX, quando a medicina passa a estudar o sexo, seguindo o modelo até então utilizado pela Igreja: a confissão/pecado. Assim surge a "Scientia Sexualis" (Ciência Sexual), conceituada por Foucault, como o corpo de conhecimento o qual foi construído por dados coletados pelos médicos da época. Os dados obtidos por Foucault foram relatados por pacientes por meio de entrevistas, cartas, autobiografia sobre pensamentos, crimes, sonhos, infância e sexo. Figueiró (1996, p. 62), baseada na obra de Foucault, destaca a importância de esclarecer que os discursos coletados dos pacientes eram justamente pautados em "aberrações, perversões, extravagancias excepcionais, enfim, em sexualidades periféricas”.

Neste contexto, o que antes era visto como pecado pela Igreja passou a ser encarado como doença, segundo a medicalização do sexo. Essa prática médica, com política de higiene, passou a exercer um controle sobre a vida social e sexual das pessoas, propondo-se a assegurar o vigor físico e a pureza moral. É possível verificar nos dias de hoje, da era tecnológica, que o acesso à informação é fácil e rápido, embora nem sempre seguro, que a sexualidade é vista como tabu, por muitos, associada somente ao ato sexual. É necessário entendermos o que é a sexualidade. Foucault (1988), definiu a sexualidade como sendo:

[...] o nome que se pode dar a um dispositivo histórico: não à realidade subterrânea que se apreende com dificuldade, mas à grande rede da superfície em que a estimulação dos corpos, a intensificação dos prazeres, a incitação ao discurso, a formação dos conhecimentos, o reforço dos controles e das resistências, encadeiam-se uns aos outros, segundo algumas grandes estratégias de saber e de poder (p. 100)

Foucault (1988) trouxe um olhar diferenciado ao conceito de sexualidade, não mais higienista, biológico, e sim, considerando a sexualidade como fenômeno histórico-cultural e político. Suas reflexões nos revelam que o poder sobre a sexualidade não está voltado somente para as relações de dominação, negação, proibição nem centralizado apenas do Estado, tudo faz parte de um sistema de poderes em que as relações e instituições sociais, como as escolas, famílias também exercem poder. Nesse sentido, Altmann (2001, p. 577), baseada nas ideias de Foucault, discorre que "o poder se produz a cada instante, em todos os pontos, em toda relação", em todas as partes, em todas as instituições, inclusive na escola. 
Segundo Silva e Neto (2006, p.186) a família, desde o nascimento da criança, incute o que é permitido ou não em matéria de sexualidade, nem sempre de forma verbalizada. Desse modo fica a cargo da escola, informar e esclarecer quaisquer dúvidas quanto à temática da Sexualidade.

$\mathrm{Na}$ escola, os professores discutem, consciente ou inconscientemente, noções sobre Sexualidade e Educação Sexual, por meio de verbalizações e/ou posturas, podendo ser positivas e instrutivas ou repressoras e castradoras (SILVA e NETO, 2006, p. 186). Temáticas ligadas à sexualidade fazem parte do cotidiano dos estudantes, seja na música, mídia, livros ou em conversas com os colegas. Omitir e/ou ignorar questões ligadas à sexualidade não são atitudes adequadas a serem tomadas quando se tem a missão de formar cidadãos críticos e comprometidos com suas escolhas.

Para Figueiró (1996, p. 17), a Educação Sexual é “toda ação de ensino-aprendizagem sobre a sexualidade humana, seja a nível de conhecimento de informações básicas, seja a nível de conhecimento e/ou discussões e reflexões sobre valores, normas, sentimentos, emoções e atitudes relacionadas à vida sexual".

Figueiró (1995) afirma que temas relacionados à Educação Sexual são ricos, no sentido de abrir caminhos para o desenvolvimento da criticidade dos alunos e para conquista da democracia. A autora aborda que, além de se tratar essa temática da sexualidade na escola, o/a aluno(a) deve ser ensinado(a)/estimulado(a) quanto à leitura para que se torne um auto educando(a).

A Educação Sexual e a formação do leitor são, pois, mutuamente complementares, uma vez que, aproveitando a temática sexualidade, que é um assunto mobilizador (de interesse e curiosidade de pessoas das variadas idades), pode-se, usando os livros de Educação Sexual, levar o sujeito a desenvolver o gosto e o hábito da leitura. Em contrapartida, isso reforça a Educação Sexual, podendo constituir-se numa eficaz estratégia que auxilie a suprir a necessidade, já discutida, de levar os educandos a terem repetidas oportunidades de rever, integrar e ampliar seus conhecimentos sobre sexualidade (FIGUEIRÓ, 1995, p.721).

Existe uma preocupação para que a educação sexual aconteça nas escolas, já que na mídia, de uma forma ou de outra, ela está acontecendo (MAISTRO; ARRUDA; JUNIOR, 2009). Porém, algumas abordagens feitas pela mídia podem não ser seguras, induzindo a preconceitos e traços de conservadorismo, ainda presentes na sociedade brasileira. Nesse sentido, Carvalho (2009, p. 9) afirma que:

(...) a TV fornece conhecimentos sobre situações pouco discutidas nos cotidianos de algumas pessoas, contribui, também, para induzir comportamentos e formar opiniões, pois, por mais contraditório que nos pareça, ao assistirmos uma cena de nudez, um triângulo amoroso, romances heterossexuais retratados, são as representações estereotipadas, os interditos e os valores conservadores que estamos assimilando. Final feliz, uniões duradouras, heróis e heroínas brancos e 
heterossexuais, homossexual com trejeitos afeminados, beijo gay censurado... dispositivos morais que refletem a preferência sedimentada da sociedade brasileira. A mídia reflete a média: a sociedade no Brasil é conservadora e faz com que a televisão tenha um projeto educacional conservador, cuja finalidade está longe de abalar, ou ao menos questionar, a norma eleita na sociedade.

Conforme a autora, vivemos em uma sociedade conservadora, então se faz necessário iniciarmos uma reflexão acerca desta temática, seja em casa, no âmbito familiar ou na escola. Embora essa não seja uma tarefa fácil, Oliveira (2009, p.182) mostra que:

[...] abordar o tema na escola não é fácil, principalmente, se o professor não estiver seguro e preparado para tal abordagem. Deveria ser, mas não é. Os mitos e preconceitos vindos da antiguidade têm refletido no contexto atual. Fato semelhante ao ocorrido em períodos passados, quando a sexualidade foi associada a "coisas feias", impróprias e restritas somente a adultos. Os jovens do atual contexto, envoltos em tantas informações e precoces em relação ao sexo, são, ao mesmo tempo carentes de esclarecimentos as suas dificuldades e dúvidas sobre a sua sexualidade.

Figueiró (2009) ressalta que ensinar sobre sexualidade no espaço da escola não se limita a colocar em prática estratégias de ensino, envolve ensinar, através da atitude de educador(a), que sexualidade faz parte de cada um de nós e pode ser vivida com alegria, liberdade e responsabilidade. "Educar sexualmente é, também, possibilitar ao indivíduo o direito a vivenciar o prazer" (FIGUEIRÓ, 2009, p.163). Não se limita somente a prevenção de gravidez e doenças sexualmente transmissíveis, em especial a AIDS, por sua vez um educador sexual deve valorizar a informação de conteúdos relacionados com a sexualidade para "num contexto de debate, para, através da discussão da sexualidade, levar a tomada de consciência da cidadania" (FIGUEIRÓ, 1996, p. 41).

Conforme Altmann (2001), em virtude do crescimento de casos de gravidez indesejada, entre adolescentes, e do risco da contaminação pelo HIV, o tema Orientação Sexual (PCN) foi proposto como tema transversal a ser trabalhado ao longo de todos os ciclos de escolarização. A autora mostra que:

A sexualidade é um "negócio de Estado", tema de interesse público, pois a conduta sexual da população diz respeito à saúde pública, à natalidade, à vitalidade das descendências e da espécie, o que, por sua vez, está relacionado à produção de riquezas, à capacidade de trabalho, ao povoamento e à força de uma sociedade. (ALTMANN, 2001, p. 576).

Nesse sentido, podemos inferir que a sexualidade está ligada não somente à individualidade de cada ser, sua essência, sua história, mas que também está ligada à cultura e política da sociedade em que ele está inserido. 


\section{EDUCAÇÃO SEXUAL E FORMAÇÃO DE PROFESSORES}

Segundo Silva e Santos (2011), historicamente a comunidade escolar vem delegando aos professores de Biologia e Ciências a responsabilidade de orientação e conteúdo sobre a o tema Educação Sexual. Para Rodrigues e Salles (2011, p.2), "infelizmente tal prática ou discussão ainda não ocorre de maneira natural e sistemática, entendida como parte das várias dimensões do ser humano". Talvez resida aí uma das principais dificuldades dos docentes das diversas áreas em sentir-se preparados para discutir o tema.

Segundo o PCN (BRASIL, 1997, p. 31), os temas transversais correspondem a questões importantes, urgentes e presentes sob várias formas, na vida cotidiana. Os mesmos devem ser incorporados nas áreas já existentes e no trabalho educativo da escola.

Moizés e Bueno (2009) afirmam que a transversalidade implica na necessidade de o/a professor/a não apenas dominar o conteúdo programático da matéria que é responsável, como exige conhecimento do conjunto das disciplinas curriculares ofertadas no ensino, e que tenha habilidade para inserir temas transversais que fogem da sua área de formação e especificidade.

A transversalidade diz respeito à possibilidade de se estabelecer, na prática educativa, uma relação entre aprender na realidade e da realidade de conhecimentos teoricamente sistematizados (aprender sobre a realidade) e as questões da vida real (aprender na realidade e da realidade)... (BRASIL, 1997, p. $31)$.

Figueiró (2009) afirma que todos educamos sexualmente nossos alunos, mesmo que não tenhamos consciência, por meio da forma como lidamos com as situações do dia-a-dia. Nóvoa (2009, p.15) explicita que "ensinamos aquilo que somos e que, naquilo que somos, se encontra muito daquilo que ensinamos". Com a nossa postura, contribuímos para que o aluno forme uma imagem positiva ou negativa do corpo, da sexualidade e do relacionamento sexual.

(...) o professor deve preparar-se para a intervenção prática mediante leituras e discussões e tenha um espaço grupal de supervisão continuada e sistemática que possibilite uma reflexão sobre essa prática e sobre seus próprios valores e limites, o que o ajudará a ampliar sua consciência em relação à sexualidade e à visão de mundo, além de assumir uma postura ética na sua atuação (SILVA e NETO, 2006, p.187).

Nesse sentido, Nóvoa (2007) afirma que um bom professor busca novas estratégias e possibilidades de ensino e aprendizagem, consegue fazer a diferença em prol da educação.

Podem inventar tecnologias, serviços, programas, máquinas diversas, umas a distância outras menos, mas nada substitui um bom professor. Nada substitui o 
bom senso, a capacidade de incentivo e de motivação que só os bons professores conseguem despertar. Nada substitui o encontro humano, a importância do diálogo, a vontade de aprender que só os bons professores conseguem promover. É necessário que tenhamos professores reconhecidos e prestigiados; competentes, e que sejam apoiados no seu trabalho, o apoio da aldeia toda. Isto é, o apoio de toda a sociedade. São esses professores que fazem a diferença. É necessário que eles sejam pessoas de corpo inteiro, que sejam profissionais de corpo inteiro, capazes de se mobilizarem, de mobilizarem seus colegas e mobilizarem a sociedade, apesar de todas as dificuldades (NOVOA, 2007, p.18).

Rodrigues e Salles (2011, p.2) revelam que um dos aspectos que ainda representa um limite com relação à formação de professores está associado à mobilização para o tema. Isso ainda permanece no âmbito da opção pessoal, ou seja: se o/a professor está sensibilizado para a necessidade ou tem interesse pelo tema, ele/a estuda e se propõe a discutir, caso contrário, não.

Nesse sentido, Jardim e Brêtas (2006), abordam que diante da necessidade de atingir expectativas dos alunos de discutir não só questões biológicas, faz-se necessário abordar questões que envolvem sentimentos, valores, moral e ética, é necessário construir e instrumentalizar professores com habilidades essenciais, proporcionando a eles condições de ampliar e reciclar seu conhecimento, por meio de programas de atualização e capacitação direcionados à sexualidade.

A possibilidade de uma formação continuada nesta temática deve avançar, pois na maioria dos cursos de formação inicial, sejam da saúde ou da educação, não estão contempladas discussões que mostrem quem são os sujeitos de direitos que serão apresentados a nós no cotidiano do nosso trabalho e nem como deveremos abordálos (RODRIGUES e SALLES, 2011, p. 3).

Nesse contexto, Maia et. al. (2006) afirma que a educação sexual aliada à formação de professores contribui para enriquecer a prática docente na escola, favorecendo uma relação em que todos se beneficiariam professores, estudantes e familiares. Nóvoa (2009) destaca que o trabalho colaborativo e coletivo facilita a intervenção dos projetos educacionais.

Silva e Neto (2006) reforçam a importância de a universidade assumir a formação dos profissionais do magistério. Para tal, é necessário, entre outros fatores, a sensibilização e a preparação dos docentes, inclusive da Educação Superior, que também não foram formados para o trabalho com a temática.

No mesmo sentido, vários autores como Figueiró (2009); Silva e Neto (2006); Rodrigues e Salles (2011); Silva e Santos (2011) acreditam que a formação inicial dos professores tem deixado a desejar no que tange a abordagem da temática sexualidade, sendo necessário também uma formação continuada para que os professores possam abordar a Educação Sexual com segurança em sala de aula. Eles acreditam que os cursos de graduação devem abordar essa temática em disciplinas obrigatórias nas licenciaturas. 


\section{LICENCIATURA EM CIÊNCIAS NATURAIS NA FUP}

Segundo o Projeto Político Pedagógico do Curso de Licenciatura em Ciências Naturais (2013) a Universidade de Brasília foi criada em 1962, e em 2002 a UnB possuía em torno de 22 mil alunos matriculados entre a graduação e pós-graduação, sinalizando a necessidade de expansão para além do campus Darcy Ribeiro. A FUP foi o primeiro campus avançado da Universidade de Brasília, criado por ocasião do processo de expansão da Educação Superior Brasileira. Segundo o Regimento interno da FUP a proposta do curso tem a finalidade de desenvolver atividades de ensino, pesquisa e extensão de acordo com o Projeto Político Pedagógico e Institucional da FUP. A Instituição oferece atualmente o curso de Licenciatura em Ciências Naturais diurno e noturno, com duração de 8 e 9 semestres respectivamente, Gestão do Agronegócio, Gestão Ambiental e Educação do Campo.

O Curso de Licenciatura em Ciências Naturais período diurno foi concebido em 2006 e em 2009, o curso foi ampliado, oferecendo vagas também no período noturno. O curso oferece atualmente 80 (oitenta) vagas, 40 (quarenta) no diurno e 40 (quarenta) no noturno, a cada semestre, ampliando o acesso ao ensino superior na região de Planaltina e demais Regiões Administrativas do DF. O curso de CN possui objetivo de formar licenciados em ciências naturais, para atuar na área de Ciências Naturais na Educação Básica, precisamente nas séries finais do Ensino Fundamental (6 ${ }^{\circ}$ ao $9^{\circ}$ ano), com enfoque interdisciplinar, descrito no PPP:

\footnotetext{
Quer seja na educação formal ou na não-formal, a complexidade da nossa sociedade pede um profissional que saiba atuar de forma interdisciplinar. Isto requer uma maneira diferenciada de formar os profissionais e de abordar os conteúdos das ciências da natureza, ou seja, tomando-se como ponto de partida a realidade em sua complexidade, com metodologias que privilegiem a prática, a intervenção, e a interação em e entre grupos, sem perder de vista as questões éticas e humanitárias (UNB, 2013, p.8).
}

A Licenciatura em $\mathrm{CN}$ é um curso interdisciplinar, que busca desenvolver contextos pedagógicos que favoreçam o desenvolvimento de capacidades e habilidades, dentre elas postura reflexiva e crítica diante dos fatos que lhe são apresentados.

Foi realizada uma análise das disciplinas na matriz curricular ofertadas no Curso de Licenciatura em Ciências Naturais da FUP voltadas para o tema de sexualidade. É importante destacar que a busca por disciplinas foi feita de forma que a disciplina tivesse como título/tema algo relacionado às palavras Sexualidade e/ou Educação Sexual, esta análise foi realizada no período de outubro a dezembro de 2015. E neste período, o curso não apresentou em sua grade curricular nenhuma disciplina obrigatória com a temática Sexualidade ou Educação Sexual em seu título. 
Também não foi identificada nenhuma disciplina optativa com essa descrição, porém vale salientar que na FUP segundo a coordenação do curso, são ofertadas as disciplinas Abordagem do Corpo Humano e Adolescência na Escola, de natureza optativa, que trabalham com a temática da Sexualidade. Porém, nenhuma das disciplinas estava na lista de oferta para o respectivo semestre $\left(2^{\circ}\right.$ de 2015). Tendo em vista a importância da temática e como Silva e Santos (2011) destacam que o trabalho escolar com a temática da sexualidade tem ficado a cargo de professores de Biologia e Ciências Naturais, acredito ser de suma importância à formação inicial destes profissionais quanto à temática.

A Educação Sexual segundo Figueiró (1996) envolve discussões e reflexões sobre valores, normas, sentimentos, emoções e atitudes relacionadas à vida sexual. Abordar todas essas questões na escola não é fácil, principalmente porque os professores não se sentem seguros e preparados, bem como salienta Oliveira (2009) e Rodrigues e Salles (2011).

Silva e Neto (2006) acreditam que a preparação do professor para essa intervenção deve ser feita por meio de leituras e discussões que possibilitem uma reflexão sobre seus valores e sua prática. Essa prática reflexiva é muito importante, uma vez que, ensinamos aquilo que somos (NÓVOA, 2009). Este trabalho pretende contribuir com esse desenvolvimento de postura reflexiva e crítica no caso da Educação Sexual aliada à formação do licenciando em CN.

\section{METODOLOGIA}

A pesquisa possui caráter qualitativo, uma vez que as informações foram obtidas em ambiente natural, por meio de contato direto do/a pesquisador/a com os/as participantes, "a pesquisa qualitativa é uma pesquisa interpretativa, com o investigador geralmente envolvido em uma experiência sustentada e intensiva com os participantes" (CRESWELL, 2007, p. 188).

Neves (1996) revela que, diferentemente da pesquisa quantitativa que segue um plano previamente estabelecido, a pesquisa qualitativa costuma ser delineada ao longo do seu desenvolvimento. A mesma não busca enumerar ou medir eventos, seu foco de interesse é a construção de sentidos nas relações. Os investigadores qualitativos não recolhem dados a fim de confirmar ou refutar uma teoria, pelo contrário, vão construindo suas abstrações à medida que os dados vão sendo construídos (BOGDAN; BIKLEN, 1994).

Bogdan e Biklen (1994) apresentam cinco características da pesquisa qualitativa:

1. A fonte de dados é o ambiente natural:

$\mathrm{Na}$ pesquisa qualitativa, o pesquisador recolhe os dados no local onde os participantes vivenciam a questão/problema da pesquisa, pois consideram importante o contexto. 


\section{2. É descritiva:}

O material recolhido é considerado de forma minuciosa e incluem transcrições, observações, fotos, vídeos, notas de campo e outros registros. A intenção é respeitar ao máximo cada informação.

3. Interesse pelo processo e não apenas pelos resultados:

A preocupação é com o processo e com a negociação de significados.

4. Tendência de análise indutiva:

O investigador qualitativo não inicia sua pesquisa já sabendo onde irá chegar, mas vai construindo sua pesquisa à medida que recolhe informações.

5. Importância do significado:

$\mathrm{Na}$ pesquisa qualitativa, existe preocupação em considerar o significado que os participantes atribuem ao problema de pesquisa.

O presente trabalho se adequa às características descritas por Bogdan e Biklen (1994), uma vez que a pesquisa foi desenvolvida em sala de aula, todas as informações serão apresentadas de forma descritiva, utilizando citações para respeitar ao máximo a forma com que foram registradas. O interesse foi considerar todo o processo, não apenas os resultados. A realização de uma disciplina sobre a Educação Sexual para os licenciandos em Ciências Naturais foi uma construção junto com os licenciandos, de um espaço para discussão e reflexão sobre a temática e sua importância no meio educacional, contribuindo para a formação inicial dos mesmos.

\section{1. Etapas da pesquisa}

Com a finalidade de alcançar o objetivo da pesquisa, as seguintes intervenções foram realizadas: a) Elaboração da Ementa da disciplina pela pesquisadora; b) Entrega do Termo de consentimento Livre e Esclarecido para os estudantes matriculados disciplina Optativa; c) Realização da proposta - execução da disciplina; d) Análise da proposta e discussão acerca dos resultados alcançados.

\subsection{Participantes}

Participaram da disciplina/pesquisa 17 estudantes do curso de Ciências Naturais da FUPFaculdade de Planaltina. Sendo 12 participantes do sexo feminino e 5 do sexo masculino, com idade aproximadamente entre 19 até 42 anos, cursando entre o $2^{\circ}$ até o $9^{\circ}$ semestre do curso. Dos 17 apenas 8 já fizeram a disciplina de estágio supervisionado, e 1 participa de um projeto de extensão, onde desenvolve trabalhos nas escolas públicas. Os participantes não cursaram nenhuma disciplina 
ou participaram de projetos com a temática. Utilizaremos a letra " $A$ " que representa aluno, seguida de números para identificar os participantes da pesquisa, exemplo, A1, A2, A3... A15, A16 e A17, sendo seus nomes preservados. Cada participante recebeu no primeiro dia de aula o Termo de consentimento Livre e Esclarecido, contendo os objetivos e intenções da pesquisa, bem como a participação voluntária na pesquisa (Apêndice A).

\section{3. Instrumentos de pesquisa}

Foi utilizada a observação participante que segundo Ludke e André (1986) possibilita o registro de informações na presença dos participantes, favorecendo o registro das observações, por meio de anotações em um diário de bordo, no momento em que ocorriam e, posteriormente facilitou a reconstrução de diálogos considerados mais relevantes. Foi observado o interesse e a atenção dos alunos durante as aulas. Outra fonte para produção de materiais foram as rodas de conversas com convidados externos, gravações de áudio, bem como a análise documental. Segundo Lukde e André (1986) todo material escrito, que seja útil como fonte de informação, pode ser considerado um documento. Neste trabalho estão sendo considerados como documento de registro os relatórios escritos pelos alunos.

\section{4. Procedimentos de Coleta de Dados}

A disciplina proposta está na matriz curricular como Optativa, com carga horaria de 30 horas, intitulada Tópicos Especiais em Ensino de Ciências, como se trata de uma disciplina de tópicos, seu tema foi Educação Sexual. Sua divulgação ocorreu por meio de rede social (facebook) no grupo de Ciências Naturais-UNB. Foram ministradas aulas com duração de 1 hora e 40 minutos, semanalmente, durante todo o primeiro semestre de 2016, pela pesquisadora. O quadro 1 apresenta o cronograma de aulas e os conteúdos abordados conforme a ementa (Apêndice B) elaborada:

Quadro 1: Descrição de aula e tema abordado na disciplina

\begin{tabular}{|r|l|}
\hline $1^{\mathrm{a}}$ aula & Apresentação da disciplina (Ementa), conhecendo os alunos \\
\hline $2^{\mathrm{a}}$ aula & Conhecimentos básicos sobre Sexualidade \\
\hline $3^{\mathrm{o}}$ aula & Gênero e Diversidade \\
\hline $4^{\mathrm{a}}$ aula & Homens, mulheres e a ciência \\
\hline $5^{\mathrm{a}}$ aula & Novas Famílias \\
\hline $6^{\mathrm{a}}$ aula & $\begin{array}{l}\text { Roda de conversa com Prof. Diego Jácome tema: Educação Sexual em } \\
\text { diferentes espaços escolares. }\end{array}$ \\
\hline $7^{\mathrm{a}}$ aula & Violência e Abuso Sexual (Seminário) \\
\hline
\end{tabular}




\begin{tabular}{|r|l|}
\hline $8^{\mathrm{a}}$ aula & Homossexualidade na escola (Seminário) \\
\hline $9^{\mathrm{a}}$ aula & Gravidez na Adolescência (Seminário) \\
\hline $10^{\mathrm{a}}$ aula & Anatomia e fisiologia dos órgãos sexuais e Métodos Contraceptivos (Seminário) \\
\hline $11^{\mathrm{a}}$ aula & Discriminação X Solidariedade \\
\hline $12^{\mathrm{a}}$ aula & A Sexualidade na vida das pessoas com deficiências \\
\hline $13^{\mathrm{a}}$ aula & Roda de conversa com Enfermeira Regina PS1 Planaltina, tema: DSTs \\
\hline $14^{\mathrm{a}}$ aula & Recursos Didáticos \\
\hline $15^{\mathrm{a}}$ aula & Apresentação da atividade da Disciplina e Avaliação da Disciplina \\
\hline
\end{tabular}

Na disciplina ministrada foi utilizada a plataforma de Ambiente Virtual de Aprendizagem AVA (Moodle), como meio facilitador para disponibilização de materiais de estudo, textos, livros e materiais em geral utilizados durante a disciplina. Especialmente, para aproveitar o tempo em sala de aula, desta forma foi adotada uma modalidade de ensino híbrido ou Blended Learning, como é definido por Staker e Horn (2012), como um programa de educação formal que mescla momentos em que o aluno estuda os conteúdos e instruções usando recursos on-line, e outros em que o ensino ocorre em uma sala de aula, podendo interagir com outros estudantes e com o professor.

É importante destacar que o Mestrado Profissional exige que além da dissertação, seja desenvolvida uma preposição educativa (Apêndice C), ou seja, um material com fins didáticos. Desta forma, foi elaborado um material que é direcionado para o professor de Ciências Naturais e tem como objetivo favorecer a reflexão e o ensino da Educação Sexual, com sugestões de textos para leitura, discussão e reflexão, recursos didáticos para trabalhar a temática em sala de aula, entre outros, os mesmos foram utilizados na disciplina.

\section{5. Procedimentos de análise de dados}

Segundo Lüdke e André (1986, p. 45), “a análise de dados qualitativos significa trabalhar com todo o material obtido durante a pesquisa, que incluem os relatos de observação, as transcrições, as análises de documentos, entre outras informações disponíveis".

As informações obtidas foram preparadas e analisadas; para isso foi utilizada a análise de conteúdo que consiste em estudá-las minuciosamente, selecionar o que for importante e procurar um sentido, uma significação (LAVILLE e DIONNE, 1999, p.214).

Neste estudo as observações manuscritas foram digitadas, as gravações ouvidas e transcritas, os dados lidos atentamente, fez-se um recorte de informações mais relevantes e elencou-se categorias que visaram "aproximar respostas semelhantes, complementares e divergentes de modo a 
identificar recorrências, concordâncias, contradições, etc" (DUARTE, 2004, p. 222). As categorias foram formuladas com base na integração dos objetivos e nas inferências teóricas e conceituais presentes em cada questão (DUARTE, 2004). Essas informações foram elencadas em categorias que visaram relacionar os dados coletados com as concepções discutidas no referencial teórico.

\section{RESULTADOS E DISCUSSÃO}

Os resultados deste trabalho baseiam-se nos dados obtidos, que foram organizados de acordo com as seguintes categorias: a) o interesse e/ou conhecimento dos alunos por temáticas relacionados à Educação Sexual; b) Reflexões suscitadas pela Educação Sexual e suas temáticas; c) Educação Sexual e a realização de atividades dinâmicas/o uso de recursos didáticos; d) Percepções acerca da disciplina Educação Sexual. A categorização foi adotada a fim de propiciar uma melhor análise de cada um destes aspectos, mas reconhecendo que compõem um mesmo cenário.

\section{a) $\mathrm{O}$ interesse e/ou conhecimento dos alunos por temáticas relacionados à Educação Sexual}

No primeiro dia de aula, quatorze alunos estavam presentes e foi perguntado sobre a participação em alguma disciplina com a temática sexualidade, todos (100\%) afirmaram que não cursaram nenhum disciplina que abordasse Sexualidade e Educação Sexual, sendo essa a maior razão para cursarem a disciplina. Conforme descrito por A3, A4 e A7:

Não fiz nenhuma disciplina com esse tema, mas soube que tinha uma disciplina optativa nem lembro o nome, mas pelo que ouvi dizer a professora abordava um pouco sobre sexualidade, mas parece que ela não foi ofertada mais, minha amiga fez em 2012, ela até já formou. (A3)

Não fiz nenhuma disciplina, nem sabia que tinha aqui na FUP. Mas acho fundamental que tenha, é preciso para nos preparar para sala de aula. (A4)

Eu nunca nem vi alguma que tivesse essa temática. (A7)

Como é possível perceber pelos relatos acima, os alunos manifestaram que não tinham cursado nenhuma disciplina que abordasse a temática, o que demonstra que há um interesse pelo tema, uma vez que se inscreveram na disciplina, bem como é possível ver uma preocupação com a formação expressa na fala de A4. 
Em seguida foi perguntado para a turma o que eles pensavam sobre a Sexualidade. Neste momento eles ficaram mais tímidos, a maioria calada, alguns pensaram um pouco e resolveram expor suas opiniões:

Eu acho um assunto muito delicado, porque envolve muitas coisas, família, no que você acredita, como foi criada, cada caso é um caso, na sua casa pode isso, não pode aquilo, e em outros lugares é diferente. É que na verdade existe muito preconceito, então falar em sexualidade, é tipo, vamos falar de sexo. (A2).

Eu concordo que existe muito preconceito da sociedade com o tema, mas sexualidade não é só sexo, acho que envolve outras coisas, se conhecer, seus desejos, seu corpo, envolve emoções, sentimentos. (A4)

Eu também concordo com A2, é um tema considerado tabu ainda, não se fala sobre isso em casa, na minha casa a minha mãe nunca falou sobre isso comigo. E eu estou aqui para aprender sobre o tema e certamente tentar fazer diferente na minha casa e com meus alunos quando for preciso. (A1)

No momento em que A2 se pronunciava, muitos concordaram mexendo a cabeça com sinal de sim, que falar o termo sexualidade remete a se falar de sexo. Foucault (1988) aborda que a sexualidade é "um dispositivo histórico-cultural", vivencial, somos influenciados culturalmente. E desde cedo aprendemos em casa o que "é permitido ou não em termos de sexualidade, de forma direta ou indiretamente" como descreve Silva e Neto (2006). Segundo Figueiró (1996), a Educação Sexual abrange os desejos, as emoções, os valores e os sentimentos, como descritos por A4, o que remete a conhecimentos prévios sobre a temática, embora demostrando certa insegurança em sua fala.

Também é possível perceber o desejo e interesse pela temática na fala de A1, demostrando uma preocupação com sua formação não somente profissional, mas pessoal, quando revela "estou aqui para aprender e certamente fazer diferente na minha casa e com meus alunos", uma vez que o mesmo não teve nenhuma conversa ou informação fornecida pelos pais em casa.

Em seguida foi feito apresentação da professora/pesquisadora e da disciplina, como surgiu a ideia de sua criação, os objetivos e foi entregue o TCLE (Apêndice A) e a ementa (Apêndice B). Quando entregue a ementa, foi solicitado que os alunos vissem os temas que seriam abordados e se eles teriam alguma sugestão de conteúdo, algo que eles gostariam de trabalhar e que não estava presente na ementa. As respostas foram que naquele momento eles não recordavam de nenhum 
outro assunto mais importante que eles queriam ver do que todos que já estavam sugeridos na ementa.

Tivemos dois momentos de rodas de conversas com professores externos onde pudemos perceber o interesse e os conhecimentos que os participantes tinham sobre as temáticas discutidas.. A primeira roda de conversa foi com a participação do professor Diego Jácome, formado em CN, o professor aceitou o convite para compartilhar com os alunos sua experiência de trabalhos com Sexualidade em uma escola religiosa em que lecionou por três anos. O professor durante sua graduação participou do projeto sobre Sexualidade, e trabalhou com minicursos sobre a temática.

O professor Diego revelou que lecionava no ensino médio, a disciplina de Biologia, em uma escola particular, de filosofia religiosa, do Distrito Federal. No primeiro ano ele sentia que precisava fazer algum trabalho com aqueles adolescentes, pois estavam em uma fase de descobertas, relacionamentos, muitos desejos, tudo muito explicito nos seus atos, no dia a dia. Também percebia que havia muito machismo, um certo desrespeito com as meninas, por conta do gênero. E decidiu que era necessário falar sobre Sexualidade em sala de aula.

A princípio procurou parceria com os colegas professores da escola, mas não encontrou apoio. Decidiu ariscar por conta própria, sozinho, utilizando alguns recursos didáticos começou a trabalhar com os alunos Educação Sexual. Falando sobre gênero, trabalhando o machismo, a violência contra a mulher, métodos contraceptivos, DSTs, abuso sexual. E afirmou "quando você conhece seus alunos, consegue perceber o que está afligindo eles, por exemplo, uma vez quando falei sobre abuso e violência, percebe umas carinhas na turma, que falavam com o olhar, "eu já passei por isso". Mesmo que o aluno não fale de sua experiência, você consegue sentir pelo olhar, e de repente pode aconselhar elou informar como o aluno resolver tal situação. É muito importante essa aproximação aluno-professor”. (Professor Diego)

As perguntas começavam a surgir, e as questões foram: Como você conseguiu trabalhar sem o apoio da escola? E como trabalhava os temas na sala, qual metodologia?(A3)

A resposta ao primeiro questionamento, foi que ele teve o apoio dos pais dos alunos. “Alguns alunos chegaram em casa e relataram para os pais o que tinham visto na aula. E três mães foram até a escola falar com a direção, para saber quem era o professor e parabenizá-lo pelo trabalho, porque eles não falavam sobre o tema em casa, mas desejavam que seus filhos aprendessem, fossem informados. Ter o apoio dos pais foi fundamental, porque a partir de então o diretor me deu carta branca, tinha total liberdade nas minhas aulas"(Professor Diego).

Quanto à metodologia que usava, ele respondeu: “o mais importante era escutar os alunos, o que eles queriam saber, e sempre usando a linguagem deles, conversando com eles de forma aberta, sem demonstrar constrangimento ou vergonha em falar do assunto. Sempre que possível 
utilizava recursos didáticos, como jogos, dinâmicas, para facilitar a interação". (Professor Diego)

O professor finalizou reforçando que o papel do professor é muito importante, e que não se pode deixar os alunos inquietos, ou com dúvidas acerca de temas que envolvem sexualidade, uma vez que eles podem não tem acesso a essas informações em casa, a escola passa a ser o local onde as dúvidas podem ser trabalhadas, o professor deve buscar informação e formação para trabalhar com a sexualidade.

Como citado pelo professor, Silva e Santos (2011) ressaltam que em casa, as famílias, em sua maioria, não abordam o assunto, ficando por conta da escola essa tarefa, especialmente, aos professores de Ciências e Biologia. Bem como já destacado também por A1 no primeiro dia de aula "na minha casa minha mãe nunca falou sobre isso comigo". Os alunos mostraram se muito interessados durante toda conversa.

A nossa segunda roda de conversa teve a presença da Enfermeira Regina Célia para uma discussão sobre Doenças Sexualmente Transmissíveis (DST), a mesma trabalha no Posto de Saúde de Planaltina - DF. O trabalho teve inicio com uma dinâmica, cada aluno recebeu uma bolinha de papel de cor diferente (vermelho, laranja, verde, amarelo, ou lilás), em seguida foi solicitado que fizessem pares, uma música (forró) se iniciou e todos começaram a dançar. Em determinado momento da música foi solicitado que trocassem de pares, só que a cada parceiro de dança que o aluno tinha, era necessário trocar suas bolinhas (o aluno que tinha sua bolinha de cor lilás, trocou com seu parceiro de dança pela bolinha que ele tinha, que era vermelha, por exemplo), e assim houve várias trocas de parceiros e de cores de bolinha durante a música.

Após a música, Regina explicou que cada cor de bolinha significava um tipo de DST, e a troca de parceiros significava uma relação, que em toda relação você dá e recebe algo, é uma troca, seja de coisas boas e/ou coisas ruins, como uma doença por exemplo.

A partir daí ela falou sobre as doenças, pediu para cada aluno citar uma DST que conhecesse, abordou as vacinas para HPV e Hepatite B, e sobre prevenção. Ela deu várias dicas sobre DST, que é necessário informar nossos alunos, que precisam ser discutidos estes temas, e que pela sua experiência na área, acredita ser bem mais fácil informar, ensinar os adolescentes a se proteger. Atentou para o abuso e a violência sexual, que ocorre muito, e na sala de aula podemos encontrar alguns desses casos, e incentivar as pessoas a buscarem o serviço de saúde. E usou uma frase muito importante para chamar atenção para nós, enquanto professores "agente ensina matemática, português, ciências, ai a pessoa se apropria de tanto conhecimento, mas ela não se apropria de si mesmo, de cuidar de si mesmo, percebem como é grave”.

Isso porque, segundo ela os números de jovens infectados é cada vez maior. Os alunos demostraram bastante interesse e atenção durante a conversa houve interação e suas palavras 
incentivaram uma reflexão sobre o assunto, a maneira como Regina conduziu a conversa também chamou atenção dos mesmos, como podemos ver na fala de A5:

Achei muito interessante como foi conduzida a aula, porque no ensino médio quando o professor falava sobre DST, era, somente mostrando aquelas imagens horrorosas, que mais parecia que o objetivo era que nunca fizéssemos sexo. Hoje sem ver nenhuma imagem, eu consigo refletir sobre a importância do preservativo, e agora já tenho uma maneira de falar sobre isso com meus alunos sem gerar traumas com uso daquelas imagens, como me foi ensinado antes.

A fala de A5 demostra que um tema de grande importância pode acabar atingindo negativamente o aluno quando não abordado adequadamente. Esta discussão pode mostrar ao aluno uma outra maneira possível de trabalhar a temática. Assim como descrito nos primeiros relatos o interesse e a participação dos alunos eram perceptíveis, isso demostram que são possíveis momentos de discussão, reflexão e aprendizagem sobre Educação Sexual.

\section{b) Reflexões suscitadas pela Educação Sexual e suas temáticas}

Na terceira aula, o tema proposto foi Gênero e Diversidade, foi trabalhado dois capítulos do livro Gênero e Diversidade na Escola - GDE (MEC/SECAD, 2009), um capítulo falava sobre Gênero e o outro sobre Diversidade. A turma foi dividida em dois grupos e foi solicitado pela pesquisadora que eles lessem e discutissem sobre o tema com seu grupo e em seguida seria feita uma discussão na sala para todos, momento em que cada grupo apresentaria o que entendeu de sua leitura. Os alunos podiam sair da sala para que pudessem ler e discutir melhor entre o grupo sem atrapalhar a leitura do outro. A leitura dos capítulos acabou por tomar todo tempo da aula, uma vez que os alunos mostraram-se empolgados com o texto e a discussão entre os próprios grupos. Então foi sugerido pela pesquisadora que eles refletissem um pouco sobre o que leram e discutiram com seus colegas e escrevessem um relatório dessa leitura. Abaixo alguns trechos dos relatos:

A diversidade cultural refere-se aos diferentes costumes de uma sociedade, como: vestimentas, culinárias, religiões, tradições entre outros aspectos. $O$ Brasil, devido a sua grande extensão territorial, é um país muito rico nessas culturas, por exemplo; a diversidade religiosa, está na presença das várias crendices que existem, como os católicos, judeus, muçulmanos, evangélicos etc. Existe também uma grande diversidade de cor, raça, opções sexuais que deveríamos levar para um lado bom, pois o país possui essa variedade de pessoas e de vivências, existem formas diferentes de viver a vida que devem 
ser respeitadas. Mas sempre têm pessoas que têm preconceitos ou descriminações, que vê isso com uma visão negativa. O respeito tem que estar lado a lado com a diversidade sempre para que assim, possamos olhar para as diferenças dos outros com bons olhos e a escola deve trabalhar esse assunto em qualquer época do ano, não apenas em datas comemorativas, como o dia da consciência negra etc. Para que assim os alunos possam construir suas próprias identidades e aprender a respeitar as diferenças do outro. Como diz um trecho do livro "Trata-se, portanto, de tarefa transdisciplinar, pela qual todos os educadores e educadoras são responsáveis." $O$ direito e o respeito à diversidade devem ser trabalhados no contexto escolar, independentemente da disciplina, do professor, da idade dos estudantes. Para que exista mais igualdade no país e valorização das diversidades existentes. (A8)

O texto sobre diversidade aponta a necessidade da mudança profunda na escola quanto ao respeito às diferenças. Não é fácil desconstruir algo que está estruturado há tanto tempo na sociedade como os preconceitos em relação à orientação sexual, ao gênero, às questões étnico/racial, por conta da cultura e das ideias de uma estrutura social antiga, mas é necessário dar o primeiro passo, que acredito ser refletirmos e pensarmos como podemos mudar essas desigualdades Precisamos refletir e levá- los (nossos alunos) a refletir que as diferenças existem e são naturais e precisam ser respeitadas.

Muitas vezes tratamos sexo e gênero como sinônimos, mas a verdade é que sexo refere-se ao aspecto biológico, anatômico, enquanto gênero diz respeito à construção social do sexo, ou seja, a maneira de ser de homens e mulheres determinados pela cultura. Desde muito pequenos, somos condicionados a aprender a nos comportarmos como homens e mulheres, desde o modo de falar, se sentar, se vestir, até os brinquedos que devemos ou não usar. Desde sempre, as mulheres foram destinadas ao espaço privado e aos afazeres domésticos, de modo que seu futuro deveria ser de se casar, ter filhos, cuidar da casa e ser sustentada pelo marido. Muito desse quadro já foi melhorado, visto que atualmente há um grande número de mulheres que tem apresentado independência da figura masculina. No entanto, isso não é o suficiente, considerando que a personalidade feminina ainda é muito estereotipada e desproporcionalmente tratada. No mercado 
de trabalho, por exemplo, ainda vemos diferenças salariais significativas para homens e mulheres que exercem o mesmo cargo e as mesmas funções. Ademais, vemos a distinção entre as áreas de concentrações masculinas $e$ femininas, senda as áreas de educação e cuidado reservadas ainda à figura feminina. Fora isso, ainda temos os estereótipos: as mulheres que se vestem com roupas curtas ou possuem a vida sexual ativa, denominadas galinhas ou putas, enquanto homens que se comportam com tais atitudes são considerados garanhões. (A9)

Desde o nascimento, nos é incumbido padrões pela sociedade. O texto cita que desde que os pais recebem o resultado do ultrassom, passa-se a "desenhar" o lugar da criança. Caso for menina, o quarto, as roupas etc será tudo rosa, caso for menino, tudo será azul e conforme o crescimento da criança, os padrões seguem: definindo como devemos brincar, com quais brinquedos, quais são as roupas que devemos usar, quais as cores dessas roupas e seguem... Segundo o texto, o conceito de gênero "homens e mulheres são produtos da realidade social e não decorrência da anatomia de seus corpos", ou seja, somos produtos de uma cultura machista, onde homens ocupam o topo. Em algum momento da vida, você já deve ter se perguntado o porquê de todas essas desigualdades, eu já me perguntei isso, e tentar compreendê-las não é uma tarefa fácil. Vimos que essas desigualdades não são em relação à anatomia dos corpos, mas sim decorrentes da educação cultural das sociedades. Devemos nos atentar ao ensino dado as nossas crianças de hoje, para que num futuro próximo estas possam estar inseridas em uma sociedade mais humana, sem tantos preconceitos. (A11)

Aliado à família, se vê também a importância do papel da escola na implantação do estudo do tema. E não apenas estudar o assunto em sala de aula, mas ter docentes atentos aos preconceitos existentes no ambiente escolar, ter docentes capazes de lidar com situações advindas de discriminação, ter docentes capazes de promover diálogos e debates, para promover inclusão e igualdade. Concordo com o trecho do texto que fala que a superação da discriminação se dá por meio de políticas públicas específicas. Contudo, penso que apenas elaborar leis ou algo do tipo não adiantaria e não seria efetivo de fato, pois a superação da discriminação deve ser também um processo de mudança de comportamentos, um processo 
de transformação de mentalidades que estão enraizadas na sociedade. Apenas assim, a igualdade, independente de diversidade e gênero, será alcançada. (A14)

Louro (2011) aborda que é necessário demonstrar que não são propriamente as características sexuais, mas é a forma como essas características são valorizadas que vai construir o feminino e o masculino. Como diz Connell (1995, p.189) "no gênero, a prática social se dirige aos corpos". É possível perceber nas reflexões descritas que os alunos se identificaram com a leitura, por exemplo, quando A11 relata o momento que os pais descobrem o sexo do bebê, "já começam a planejar o quarto, as cores, os brinquedos, tudo conforme as características já enraizadas para o feminino e o masculino". Na sua fala A8 refere se a algumas diversidades encontradas no Brasil, como cor, raça, e usa o termo "opções sexuais", o texto não utiliza esse termo, o mesmo não é mais utilizado porque na verdade não se trata de uma opção, e sim uma orientação sexual. Podemos inferir com isso, o quanto somos influenciados socialmente, porque leu-se uma palavra, mas na sua cabeça já estava fixado um conceito como opção e até involuntariamente a pessoa expressa-se dessa forma, o que não significa também que isso é ruim, só mostra a necessidade de refletirmos sobre a temática. Para que muitos mitos sejam esclarecidos na nossa sociedade. Essa discussão sobre esses termos foi realizada e esclarecida durante o seminário sobre homossexualidade.

E, como citado por A4 "não é fácil descontruir algo tão enraizado, mas é necessário dar o primeiro passo, que acredito ser refletirmos e pensarmos como podemos mudar essas desigualdades". Kelman (2010) afirma que a diversidade implica em se reconhecer distintas expressões da vida humana. A sensibilidade à diversidade humana gera inclusão social, sua negação promove a exclusão social. É preciso desigualar condições para igualar oportunidades. O desenvolvimento humano é marcado pelas diferenças, precisamos entendê-las e respeitá-las para que todos possam se desenvolver. A escola é um local onde deve ser promovido o multiculturalismo e a acessibilidade e, certamente, a inclusão.

Em outro momento foi trabalhado o texto A Ciência é masculina? É, sim senhora!, de Attico Chassot (2004), este texto, como os demais trabalhados na disciplina, ficou disponível na plataforma Moodle, para que os alunos pudessem fazer a leitura em casa e pudesse ser aproveitado todo o tempo da aula para discussão. O texto abordou um pouco a história da predominância masculina na ciência. Foi solicitado que eles falassem dessa leitura, fazendo uma ligação com o texto de gênero da semana anterior. As considerações foram as seguintes: 
do preconceito, onde, infelizmente, muitos ainda acham que a mulher é sexo frágil o que pode gerar violência, devido a civilização ainda ser masculina vemos isso na distribuição das profissões, que são ditadas quais são para cada gênero. Isso vem desde as culturas antigas, que envolve, principalmente a religião. $O$ autor faz várias citações da Bíblia de onde se encontra situações em que o homem está no topo e a mulher é submissa a ele. Sendo assim, é difícil mudar essa realidade, pois a Bíblia é o Livro Sagrado de muitas religiões. Mas cabe, também, ressaltar que, essa posição da mulher dependerá da interpretação feita por cada pessoa. Se for uma pessoa conservadora de opiniões, isso será incontestável, diferentemente se for uma pessoa crítica. Por ser um preconceito milenar e que envolve religião, torna-se difícil destruí-lo. Sendo este conceito proveniente da sociedade, a Ciência acaba seguindo o mesmo rumo. Busca-se, então, tanto na sociedade, quanto na Ciência, a equidade de gênero. Observando o exemplo do casal cientista que ganhou o prêmio Nobel e que tiveram uma filha que também conquistou o prêmio nas Ciências, nota-se essa necessidade de igualdade, pois prova-se que a mulher contribui para a ciência tanto quanto o homem, porém precisa-se que não haja preconceito para que possam ocupar lugar de igual destaque. Mostrar que a mulher não é o sexo frágil e é capaz de conquistar muitas coisas, tanto quanto os homens, é um processo lento que já vem acontecendo há bastante tempo, mas é necessário para que a mulher ganhe maior reconhecimento de sua capacidade e porque tem muito o que contribuir com a Ciência e, em consequência, para a sociedade. (A10)

Na ciência é notável a predominância masculina. Fato que não é apontado apenas no presente. $O$ texto nos traz dados que confirmam essa predominância desde tempos remotos e cita a tríplice ancestralidade grecojudaica-cristã, em que é destacado um papel feminino em sua maioria, submisso. A ideia de que a mulher é frágil, designada a trabalhos domésticos e submissa a seu esposo, foi passada por gerações. Assim como a colega (A10) disse, a Bíblia teveltem forte influência nesse sentido. Diversas são as histórias que citam mulheres submissas, vetadas de falarem em assembleias e assim sucessivamente. Ora, se o livro que é usado na maioria das religiões do mundo trata as mulheres assim, por que discordar? Talvez esse deva ser o pensamento de muitos. Bom, vimos que a história contribuiu significativamente para que o número de mulheres que se 
dedicam às Ciências ainda hoje seja tão baixo. Mas ela não está sozinha. Há outra explicação: diferenças biológicas entre homens e mulheres. O texto cita que a ciência progride rapidamente e quando a mulher se afasta por algum tempo para destiná-lo à maternidade, terá de gastar posteriormente até o dobro de tempo para se reatualizarem. Dentre outros, os métodos contraceptivos auxiliam na quebra desse paradigma. Devemos tomar consciência que algumas tradições e costumes devem sim ser quebrados e o machismo está sem dúvida no topo dessa lista. É preciso viver o presente e projetar o futuro com menos discriminações. (A1).

O que podemos destacar de muito importante no texto, mesmo depois de muito tempo e muitas conquistas a nossa ciência ainda é machista, reflexo de nossas culturas em que a mulher tem o seu espaço totalmente limitado e pré-definido, como por exemplo cuidar da casa e dos filhos. Assim como vimos no texto da aula passada. (A15)

$O$ texto retrata a sociedade e o pensamento em que ainda estamos mergulhados, apesar de tantos avanços que já surgiram e tantas conquistas que nós mulheres já alcançamos. Sim, a ciência é masculina, é machista, não só a ciência, o mundo de forma geral ainda é machista, oriundo de uma cultura, de um passado, de hierarquias, e assim como o texto e algumas colegas já citaram, de religião, da forma de interpretar alguns escritos, principalmente a bíblia. Em pleno século XXI as pessoas ainda acham que mulheres não devem se dedicar à sua vida profissional, ou ainda que quando têm sucesso na vida profissional não conseguem ter sucesso na vida pessoal, como mãe, como esposa, como família. O pensamento de que as mulheres são frágeis e devem se "proteger sob as asas dos homens" ainda predomina não somente no meio masculino, mas também em muitas mentes femininas. Porém, apesar de ainda estarmos mergulhados numa cultura, numa ciência machista, nós mulheres lutamos a cada dia para conquistar nosso espaço. Digo por experiência, no laboratório onde faço pesquisa 95\% das pessoas ativas e produtivas do laboratório são mulheres, mulheres talentosas, que lutam para mostrar que gênero não define capacidade. (A3)

De fato, um comportamento tão antigo, passado de geração para geração, não será eliminado da noite para o dia. Mudanças são gradativas. As mudanças de comportamento devem começar no pensamento. Não adianta querer que as pessoas mudem de atitude se não forem educadas para a 
mudança. (A16)

A escolha do texto foi para questioná-los sobre o machismo, sobre o papel da mulher no meio científico. Os relatos mostram que todos conseguem se enxergar numa sociedade machista, que é preciso mudanças, que reconhecem a mulher como forte e não como sexo frágil, percebem as grandes conquistas femininas alcançadas ao longo do tempo. A ligação percebida entre os relatos e reflexões dos textos é a mulher como gênero frágil e o homem como centralizador do poder. Também é perceptível o poder cultural que influência pensamentos e ações, e perpassa por gerações e gerações como descreve A16.

$\mathrm{Na}$ aula sobre a Sexualidade na vida das pessoas com deficiência, foi apresentado um filme chamado “As Sessões” (2012), que conta a história de Mark, paralisado e confinado a um pulmão de aço desde os seis anos de idade, que aos trinta e oito anos, decide enfrentar o desafio mais difícil de sua vida, perder a virgindade. Com a ajuda de uma terapeuta, de um sacerdote compreensivo e de seu próprio otimismo e humor. O filme teve duração de noventa e cinco minutos, logo, não houve tempo suficiente para discussão em sala. Foi solicitado aos alunos que escrevessem suas percepções a respeito do filme, respondendo algumas indagações como: o que podemos concluir sobre a sexualidade na vida das pessoas com deficiências de acordo com o filme? O que pensam do papel da substituta sexual (a terapeuta)? E sobre a postura do padre? Os relatórios produzidos trouxeram as seguintes reflexões:

As pessoas com deficiência, por terem limitações sofrem bastante preconceito e quando se trata de sexualidade na vida delas também não é diferente. A verdade é que a sexualidade faz parte da vida de todos, tanto das pessoas com algum tipo de deficiência física, quanto das pessoas que não possuem. A sociedade enxerga o deficiente físico como alguém que: deve que ser cuidado e protegido. Não acredita na possibilidade da vida sexual deles, julgam ser incapazes, já que, possuem limitações físicas. E até a própria pessoa acaba acreditando nisso, acha que não será capaz e muitas vezes nem tenta. A substituta sexual trabalhou realmente isso no ator, mostrou que ele tinha capacidade de ter uma vida sexual, mostrou o próprio corpo dele para ele, pois ele precisava se conhecer, precisava saber onde ela iria tocar. Ela conversava e iniciava sempre de uma forma que o ator fosse se sentir a vontade, e que conseguisse trabalhar as limitações de seu corpo sem acontecer nada constrangedor, pois assim ele poderia desistir e $r$ realmente se julgar incapaz. O Papel do Padre foi fundamental, pois diferente do que poderíamos pensar, 
ele ouvia o amigo e percebia o quanto eram importantes aqueles momentos, pois iriam acabar com a angústia que ele tinha de nunca ter se relacionado com alguém. $O$ Padre buscou compreender o ator como pessoa, antes de fazer algum julgamento baseado na Igreja sobre o seu comportamento. (A6)

Podemos ver que pessoas com alguma necessidade especial tem uma grande dificuldade em encontrar um parceiro, para a sociedade pessoas com certas necessidades não devem ter relações sexuais, é como se essas pessoas não tivessem o direito de ser felizes e de realizar seus desejos sexuais, sendo que e uma necessidade natural do corpo. A dificuldade que o ator enfrenta no filme e um exemplo disso. É mais difícil para essas pessoas encontrarem alguém que queira se relacionar com elas a ponto de terem relações sexuais. Não sei se por medo de que não correspondam suas expectativas emocionais ou por pura discriminação. Todos nós temos direito de amar e ser amado independentemente das nossas limitações. Nunca imaginei que existisse substituta sexual, uma mulher que marca seções de relações sexuais com pessoas com necessidades especiais para prepará-las para ter uma vida sexual, interessante método, já que e uma terapia que envolve sexo entre profissional e paciente como forma de resolver algum problema sexual que os pacientes tenham. A posição do padre no filme foi novidade, pois ele sendo um sacerdote religioso não esperava que ele apoiasse a decisão do amigo de ter relações sexuais sem casar e ainda com uma pessoa que recebia para isso, mas ele viu que estava sendo angustiante para o amigo não encontrar ninguém que quisesse ter um relacionamento amoroso, então ele como amigo apoiou a decisão do protagonista. (A2)

Baseando não somente pelo filme mas de um modo geral, é bem notável a dificuldade que um deficiente físico sofre, a começar pelos julgamentos que são proferidos por pessoas "normais", onde pensam que o prazer é algo impossivel para as pessoas com deficiência. Na nossa sociedade com certeza ainda é forte o preconceito que algumas pessoas têm, onde baseiam-se em uma estética impecável, todos procuram corpos e rostos perfeitos quando o que oferecem nem sempre é o mesmo, isso exclui totalmente os deficientes do padrão e os impedem muita das vezes de ter um relacionamento seja sexual ou até mesmo amoroso. Achei na pessoa da substituta sexual uma postura que chega a ser praticamente "perfeita", ela humaniza toda a situação e faz com que ele sinta-se especial e também que ele pode sim como 
qualquer outro fazer uma mulher sentir prazer. Coisa que ela prova! O padre se mostra alguém que poucas pessoas entenderiam, pois ele deixa o lado dele humano e emocional acima do lado religioso e acaba se revelando um amigo dele, a cada conversa uma experiência era contada a ele, e assim foi até o tão sonhado dia em que perdeu a virgindade. O filme em si é uma obra que deve ser assistida por muitos para que o paradigma de que deficientes físicos não conseguem sentir prazer possa ser quebrado.(A7)

A sexualidade dos deficientes é algo pouco falado, imagino que pelo fato de as pessoas acharem que geralmente pessoas com deficiência perdem a sexualidade em detrimento do físico, eu mesma nunca parei para pensar na sexualidade das pessoas com alguma deficiência, mas esse filme é maravilhoso e nos leva a pensar e a fazer uma autocrítica em relação a isso, me fez refletir e querer propagar essa ideia de que pessoas com deficiência além de não serem inválidas como algumas pessoas pensam, as pessoas deficientes continuam vivendo trabalhando e sentindo prazer também. Quanto à substituta sexual eu achei muito interessante é uma ideia muito boa, porém é algo a ser pesquisado o caso de cada paciente, pois pode causar problemas psicológicos, já que o envolvimento pode ser grande ou até mesmo a pessoa se sentir sozinha após o término das sessões. A postura do padre ao meu ver foi super importante para ajudar no desenvolvimento do personagem principal, em momento algum achei a postura dele errada, pois mesmo se eu fosse católica penso que até mesmo dentro da instituição religiosa há necessidade de analisar a situação de cada pessoa e para ele ficou nítido que aquela experiência sexual era importante. (A4)

Mas uma vez podemos perceber com os relatos que as reflexões dos alunos mostram uma abertura para novos conhecimentos a respeito da Educação Sexual. O que confirma o que o Figueiró (2009) nos diz, é preciso falar sobre sexualidade, ela está presente em nós, em nossa sociedade. Precisamos aprender mais, discutir mais e refletir mais essas temáticas. Com relação ao filme na aula seguinte antes de iniciar o novo tema, a pesquisadora questionou aos alunos se tinham gostado do filme, mesmo tendo recebido os relatórios, queria escuta-los, gerando o seguinte discurso:

Professora/pesquisadora: Então, pessoal, o que acharam do filme da nossa última aula?

A1: Ah eu gostei muito, professora, e confesso que nunca tinha parado para pensar sobre isso.

Professora/pesquisadora: E porque será que nós não paramos para pensar 
sobre isso? (nesse momento um silêncio tomou conta de toda a sala, passouse alguns instantes e Al respondeu)

A1: é porque o preconceito está tão impregnado na gente, que não nos passa pela cabeça que eles podem e sentem prazer, desejos etc. Nossa, professora! Agora percebo que esse preconceito estava dentro de mim, o filme me fez refletir muito sobre isso, como nós julgamos sem conhecer o outro. A partir de agora tenho uma nova visão sobre o tema. Obrigada! Professora/pesquisadora: Que bom!

É preciso esclarecer que "a sexualidade faz parte da vida de qualquer ser humano, seja uma pessoa com deficiência ou não" (CERTEZA, p. 1, 2013). A escolha do filme foi para que os alunos se sensibilizassem e pudessem perceber, que as diferenças existentes entre as pessoas não são um obstáculo para os relacionamentos, bem como trabalhar o preconceito existente com as pessoas com deficiência, e reforçar que a sexualidade faz parte da vida de todos nós. Ainda é possível associar o preconceito que foi ressaltado na reflexão sobre pessoas com necessidades especiais, com o preconceito de gênero e de diversidade. É muito importante que consigamos reconhecer que somos pessoas que tem preconceitos para que possamos refletir e mudar esse pensamento como descrito por A1.

\section{c) Educação Sexual e a realização de atividades dinâmicas/o uso de recursos didáticos}

As aulas seguintes, sobre homossexualidade, violência e abuso sexual, gravidez na adolescência, anatomia dos órgãos sexuais e métodos contraceptivos foram apresentadas em forma de seminários, a turma foi dividida em quatro grupos e cada grupo ficou responsável pela apresentação de um tema. No quadro 2 é apresentado os temas e como cada grupo trabalhou a temática em sala:

Quadro 2: Temas e forma de apresentação dos seminários

\begin{tabular}{|l|l|}
\hline \multicolumn{1}{|c|}{ TEMA } & \multicolumn{1}{|c|}{ FORMA DE APRESENTAÇÃO } \\
\hline Homossexualidade & $\begin{array}{l}\text { O grupo fez uma exposição utilizando data } \\
\text { show, onde abordaram conceitos, direitos e } \\
\text { conquistas alcançadas (união estável, adoção de } \\
\text { crianças, etc), preconceito e discriminação. }\end{array}$ \\
\hline Violência e Abuso Sexual & $\begin{array}{l}\text { O grupo trouxe inicialmente uma música } \\
\text { (Rosas) a qual abordavam a violência doméstica }\end{array}$ \\
\hline
\end{tabular}




\begin{tabular}{|l|l|}
\hline \multirow{1}{*}{ Gravidez na Adolescência } & $\begin{array}{l}\text { vivida por uma mulher. Também foi feita uma } \\
\text { exposição com uso de data show onde foi } \\
\text { abordado conceitos sobre violência e abuso, as } \\
\text { formas de violência (física, sexual, moral, } \\
\text { psicológica e patrimonial) segundo a Lei Maria } \\
\text { da Penha, feminicídio e o caso Louise da UnB. }\end{array}$ \\
$\begin{array}{l}\text { O grupo fez uma exposição com utilização de } \\
\text { data show, abordando alguns "porquês" da } \\
\text { gravidez na adolescência, suas consequências, } \\
\text { rejeição ao bebê, fracasso escolar, mudança na } \\
\text { vida de pais adolescentes, aborto, formas de } \\
\text { prevenção. Utilizaram vídeos relatando alguns } \\
\text { casos de adolescentes grávidas. }\end{array}$ \\
\hline Anatomia dos órgãos sexuais e & $\begin{array}{l}\text { O grupo utilizou uma dinâmica inicial para } \\
\text { trabalhar os mais variados nomes que damos aos } \\
\text { órgãos sexuais. Em seguida também fizeram } \\
\text { uma exposição do conteúdo com uso do data } \\
\text { show abordando a anatomia dos órgãos e } \\
\text { mostrando os principais os métodos } \\
\text { contraceptivos para prevenção de uma gravidez } \\
\text { indesejada e das DST. }\end{array}$ \\
\hline antraceptivos &
\end{tabular}

Os grupos apresentaram os seus temas utilizando recursos comuns em todos os casos como o uso do data show para exposição dos conteúdos. Houve uma variação de recursos, como, música, vídeos e dinâmicas. Durante as apresentações os alunos participaram ativamente das apresentações dos colegas, uma vez que, todos os grupos conduziram a discussão da temática em conjunto com a sala, sempre indagando e questionando os colegas acerca do tema abordando, o que propiciou uma troca de informações e aprendizagem.

Pensando na atividade final e avaliativa, tivemos uma aula sobre recursos didáticos que teve como convidada a professora Samara Anjos, que é formada em Ciências Naturais, mestre em Ensino de Ciências e participou juntamente com a pesquisadora de um projeto de extensão sobre Sexualidade. O objetivo da aula foi demonstrar para os alunos como a temática pode ser trabalhada em sala de aula com auxílio de recursos didáticos. Foi apresentado o conceito de recursos didáticos, que segundo Souza (2007, p.111), "é todo material utilizado como auxilio no ensino - aprendizagem 
do conteúdo proposto para ser aplicado pelo professor a seus alunos". O material didático é um instrumento de trabalho na sala de aula: informa, cria, induz à reflexão, desperta outros interesses, motiva, sintetiza conhecimentos e propicia vivências culturais, sua aplicabilidade enriquece a prática docente (BRASIL, p.79, 1998).

Com sua experiência, a professora Samara apresentou aos alunos exemplos de atividades desenvolvidas nos minicursos ministrados nas escolas públicas do DF, como descrito no quadro 3:

Quadro 3: exemplos de atividades e sua descrição.

\begin{tabular}{|c|c|}
\hline ATIVIDADE & DESCRIÇÃO \\
\hline Semáforo & Exposição de dúvidas acerca do tema. \\
\hline Vocábulos & $\begin{array}{l}\text { Palavras e conceitos inerentes aos temas } \\
\text { abordados }\end{array}$ \\
\hline Transformações biológicas e psicológicas & $\begin{array}{l}\text { Identificação das principais mudanças no } \\
\text { corpo pós-puberdade e durante a fase da } \\
\text { adolescência }\end{array}$ \\
\hline Desenvolvendo a responsabilidade & $\begin{array}{l}\text { Os alunos deverão ter o máximo de cuidado } \\
\text { com o ovo (mascote), durante as três semanas } \\
\text { não poderão deixá-lo na chuva ou exposto ao } \\
\text { sol nem quebrá-lo. Eles deverão assumir a } \\
\text { responsabilidade de cuidar e proteger o } \\
\text { mascote como se fosse uma criança. }\end{array}$ \\
\hline Aspectos socioculturais da sexualidade & $\begin{array}{l}\text { As relações existentes, diferenças entre ficar e } \\
\text { namorar. Discussão de temas como "Ficar é o } \\
\text { começo para namorar", "Todos os namorados } \\
\text { transam". Vamos tratar ainda de temas como } \\
\text { meu primeiro amor, primeiro beijo, as células } \\
\text { que movimentam o corpo durante o beijo e } \\
\text { quando o sentimento "gostar" começa a ficar } \\
\text { evidente. }\end{array}$ \\
\hline Mito $\mathrm{x}$ verdade & Afirmativas expostas para julgamento. \\
\hline Gravidez/metódos contraceptivos/DST's & $\begin{array}{l}\text { Modelos anatômicos dos períodos de } \\
\text { gestação. Painel ilustrativo com métodos } \\
\text { contraceptivos e Informativos/folderes da } \\
\text { secretaria de saúde. }\end{array}$ \\
\hline
\end{tabular}




\begin{tabular}{|l|l|}
\hline Situações Problemas & $\begin{array}{l}\text { Organizadas de acordo com a faixa etária dos } \\
\text { estudantes, são aplicadas adotando-se a } \\
\text { dinâmica da batata quente. }\end{array}$ \\
\hline
\end{tabular}

Todas as atividades descritas no quadro acima foram confeccionadas pelos participantes do projeto de extensão de Sexualidade, dentre eles, a convidada e a pesquisadora, para realização dos minicursos. Esta aula foi importante para os alunos, para que os mesmos pudessem perceber várias possibilidades de se trabalhar com a temática, bem como foi um exemplo para os mesmo, pois a atividade final avaliativa da disciplina que consistia na elaboração de uma aula com a temática da Educação Sexual para o Ensino Fundamental séries finais, com a produção de um recurso didático para sua aula.

A aula final da disciplina foi destinada para apresentação da proposta de uma aula que os alunos planejaram para séries finais do ensino fundamental, a atividade foi feita em grupos, o tema foi de livre escolha para o grupo, dentro da temática da Educação Sexual e que tivesse um recurso didático como estratégia de ensino. Eles não foram para as escolas, mas a proposta foi que planejassem como seria essa aula na escola de fato. E os grupos apresentaram para a turma suas propostas e a professora Samara esteve presente para ver os resultados. O quadro 4 mostra os temas, os recursos produzidos por cada grupo, o objetivo da aula, a série/ano que se direcionavam e a descrição da atividade.

Quadro 4: Temas e recursos didáticos elaborados, objetivos, série/ano e descrição da atividade

\begin{tabular}{|c|c|c|}
\hline TEMA/RECURSO DIDÁTICO & OBJETIVO & SÉRIE/ANO-DESCRIÇÃO \\
\hline Corrida da Fecundação & $\begin{array}{l}\text { A atividade tinha como } \\
\text { objetivo compreender a } \\
\text { anatomia e fisiologia do } \\
\text { sistema reprodutor e } \\
\text { como ocorre a } \\
\text { fecundação com o jogo } \\
\text { "corrida da fecundação" }\end{array}$ & $\begin{array}{l}8^{\circ} \text { Ano. A turma se dividiu } \\
\text { em grupos, cada grupo era } \\
\text { um espermatozoide e foram } \\
\text { sorteadas perguntas sobre o } \\
\text { conteúdo abordado } \\
\text { quando a resposta era } \\
\text { correta, avançavam uma } \\
\text { casa indo ao encontro do } \\
\text { óvulo, quando o grupo } \\
\text { errava a pergunta o } \\
\text { espermatozoide permanecia }\end{array}$ \\
\hline
\end{tabular}




\begin{tabular}{|c|c|c|}
\hline & & $\begin{array}{l}\text { no mesmo local e a vez era } \\
\text { passada para o grupo } \\
\text { seguinte. }\end{array}$ \\
\hline $\begin{array}{c}\text { Diversidade e Gênero - Árvore de } \\
\text { qualidades }\end{array}$ & $\begin{array}{l}\text { O objetivo da aula foi } \\
\text { compreender } \\
\text { significado } \\
\text { diversidade e gênero, } \\
\text { aprender a respeitar as } \\
\text { diferenças, reconhecer as } \\
\text { qualidades das pessoas. }\end{array}$ & $\begin{array}{l}6^{\circ} \text { Ano. Foi distribuído } \\
\text { lápis e papel para turma e } \\
\text { solicitado para que cada um } \\
\text { retratasse o colega cujo } \\
\text { nome foi sorteado de uma } \\
\text { caixinha que continha os } \\
\text { nomes de todos os alunos } \\
\text { da turma, de modo a ser } \\
\text { fidedigno quanto às } \\
\text { características físicas (cor } \\
\text { dos olhos, da pele, cabelo, } \\
\text { etc) e as psicológicas } \\
\text { (alegre, triste, tímido, etc). } \\
\text { Em seguida quando todos } \\
\text { finalizaram foram } \\
\text { recolhidos os papéis e } \\
\text { redistribuídos entre a turma } \\
\text { de modo que cada um } \\
\text { tentasse descobrir o colega } \\
\text { desenhado. Logo após } \\
\text { ocorreu a produção de um } \\
\text { bilhete, em formato de } \\
\text { folhas, para um colega de } \\
\text { sala, elogiando-o por seu } \\
\text { modo de ser, enfatizando } \\
\text { suas qualidades, e assim } \\
\text { construindo a árvore de } \\
\text { qualidades. }\end{array}$ \\
\hline DST - Jogo d & O objetivo da aula foi & $9^{\circ}$ Ano. os participantes \\
\hline
\end{tabular}




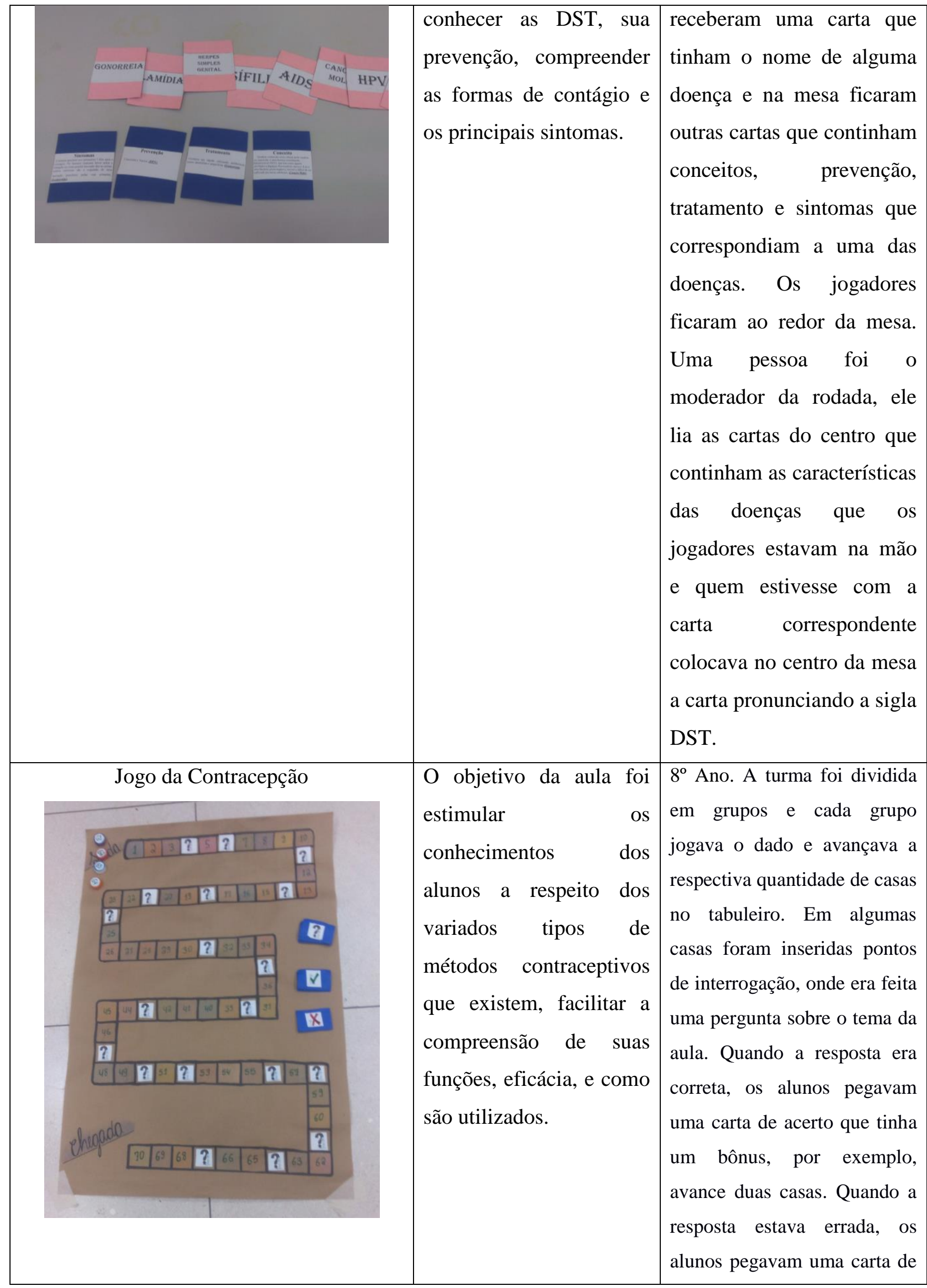




\begin{tabular}{|l|l|l|}
\hline & $\begin{array}{l}\text { erro que tinha uma punição, } \\
\text { por exemplo, volte ao início } \\
\text { do jogo. }\end{array}$ \\
\hline
\end{tabular}

Os recursos elaborados pelos alunos foram muito interessantes, ocorreu uma variação de conteúdos, todos os recursos tinham um caráter lúdico. Dois dos quatros recursos eram destinados ao $8^{\circ}$ ano. Ao final das apresentações foi realizada a avaliação das atividades, foi discutido sobre as potencialidades do recurso, se precisaria de adaptações, e algumas respostas foram:

"Acredito que todos os recursos apresentados certamente iram facilitar o trabalho com a temática da Educação Sexual, uma vez que, os jogos, as dinâmicas deixariam o clima mais leve, sem aquele receio de falar abertamente sobre o assunto com os alunos. E acho que todos podem ser trabalhados em todas as séries/anos do ensino fundamental”. (A4)

“Concerta os recursos vão facilitar a aprendizagem, os alunos gostam muito desse tipo de interação, jogos, etc, porque é diferente para eles, saem da mesmice do quadro e giz que estão acostumados”. (A8)

"Eu usaria todos esses recursos nas minhas aulas, com certeza vai facilitar a minha prática enquanto professora, como vai auxiliar no ensino aprendizagem dos alunos". (A13)

De acordo com as falas dos alunos, os recursos irão contribuir bastante com o trabalho da temática da Educação Sexual na escola. Uma última pergunta feita pela pesquisadora foi se eles tiveram alguma dificuldade na preparação da aula e construção do recurso por tratar de um assunto que envolve Educação Sexual. As respostas foram:

não professora, nenhuma dificuldade, fazer o recurso não foi uma tarefa difícil, foi legal, até porque nós já fizemos outros, eu que participo do PIBID, gosto muito, o recurso nos ajuda muito em sala de aula, acrescentado ao tema sexualidade, vai ser prazeroso trabalhar essa temática dessa forma. (A4)

eu também já fiz recurso didático para usar no meu estágio, mas nunca tinha feito sobre sexualidade, e foi muito bom, saber que os recursos podem ser utilizados em qualquer conteúdo, e como a colega falou, não será difícil trabalhar o tema usando um desses recursos, foi ótimo aprender que é possível trabalhar dessa maneira. (A9) 
Foi possível inferir que não apresentaram dificuldades na elaboração dessa tarefa, como descreve as falas de A4 e A9, bem como, visualizam o recurso como uma ótima metodologia de ensino para a Educação Sexual. Os alunos demostraram que a utilização de recursos didáticos para trabalhar a temática da Educação Sexual é viável e "torna o clima mais leve" como relata A4.

\section{c) Percepções acerca da disciplina de Educação Sexual}

Foi solicitado pela pesquisadora que os alunos escrevessem uma carta relatando o que eles conseguiram absorver da disciplina, se acrescentou algo na vida deles, se houve alguma mudança de pensamento, o que gostaram o que precisa ser melhorado e sugestões, suas percepções, foi uma forma de avaliação da disciplina. Em suas cartas não foi necessário se identificarem. Dentre as cartas recebidas, alguns relatos:

\section{Caro amigo,}

Na FUP estava sendo oferecida uma disciplina optativa que é muito interessante para nós, futuros professores de ciências, visto que ela trata de como abordar os temas de sexualidade em sala de aula. Sabemos que esses temas estão presentes nos PCN's como temas transversais e deveriam ser abordados por todas as áreas de ensino, no entanto, na prática não é bem isso que acontece. Acaba sempre sobrando aos professores de ciências abordarem esse tema transversal.

De fato o nosso curso não desenvolve subsídios para tal abordagem, visto que não se tem matérias que nos aproximem desse tema. Por sorte, descobri a disciplina de Tópicos Especiais em Ensino de Ciências, voltada para o tema de educação sexual. Pra ser sincera, antes de participar das aulas desta disciplina, não conseguia me imaginar dando aula voltada para sexualidade, já que é um tema muito delicado para ser trabalhado e ainda ser um tabu em âmbito educacional. Falar abertamente sobre o tema com os alunos causa certo pânico, pois não sabemos ao certo o que estes irão perguntar, e muito menos, como os pais poderão reagir ao saber das aulas.

A disciplina me proporcionou mais segurança para poder abordar em sala de aula conteúdos referentes à sexualidade. Hoje, apesar de ainda achar complicada essa abordagem, já consigo me imaginar tratando sobre o tema com os alunos. Afinal, são conteúdos de extrema importância, que não podem ser deixados de lado. Além disso, no decorrer das disciplinas, tivemos a oportunidade de conhecer diversos recursos e estratégias didáticas diferentes, que proporcionam a aula mais leve e lúdica.

Durante as aulas, tratamos de diversos assuntos que se tornam indispensáveis alguns questionamentos acerca destes, como por exemplo, a violência contra a mulher, os diversos preconceitos criados por nós para com aqueles que se mostram diferentes, como as pessoas portadoras de alguma 
deficiência, e também, quanto às diversas formas de discriminação, dentre outros. Enfim, são temas que se encontram presentes em todo momento na mídia, e que merecem uma discussão em sala de aula, até mesmo porque é preciso quebrar essa alienação em que nos encontramos, e o melhor lugar para tal ato é a escola, visto que formar cidadãos críticos é o primeiro passo para uma verdadeira mudança.

Acho que já deu pra perceber o quanto a disciplina é relevante. Mas como nada é perfeito, a disciplina também apresenta um ponto negativo: por ser uma disciplina de dois créditos, as aulas eram muitos curtas e o tempo passava rápido demais. Às vezes nem era possível terminar o debate, ou concluir a aula planejada. Por fim, ter pego essa disciplina foi muito significante. Realmente espero que um dia esta se torne uma disciplina obrigatória, ou que ao menos seja ofertada mais vezes na FUP. (autor não identificado)

\section{Cara Professora,}

A matéria que a senhora ministrou durante esse semestre foi de muita importância para este que a escreve. Por mais que eu não tenha participado muito em todas as aulas, eu consegui absorver bastante das coisas que foram faladas, conhecer lados sobre o assunto que eu nunca havia pensado, quebrar tabus que eu tinha, e o mais importante é que me proporcionou um gama imensa de conhecimento sobre como trabalhar com isso.

A matéria contribuiu bastante para minha formação, e espero que até o final eu possa ter mais matérias assim, pois elas nos ajudam a entender as pessoas e trabalhar de uma forma que possamos equalizar as diferenças uns dos outros. $O$ que mais me chamou atenção foi ver as diferentes formas que existem para trabalhar esse tema, até mesmo as que você usou para dar aulas, vídeos, slides, rodas de conversas, me surpreendeu muito pois na primeira aula em que tivemos que ler um texto e debater sobre ele, eu cheguei a pensar que o semestre todo seria assim, só lendo e fazendo rodas de conversa, mas acabei me surpreendendo super positivamente pois você não seguiu o padrão de normalidade de aula, e isso é o que nós, graduandos, devemos fazer também futuramente.

É uma pena que essa matéria não seja uma obrigatória para o curso, pois já vi na UnB mesmo, pessoas sem conhecimento falarem várias coisas absurdas sobre alguns temas que tratamos, como por exemplo sexualidade para as pessoas com deficiência, e com certeza eles precisam urgentemente dessa matéria. Até creio que se fosse aplicada no diurno ela seria bastante procurada.

Enfim, só quero te parabenizar pela iniciativa por "criar" essa matéria, e aposto que todos os participantes estão com conceitos bem diferentes dos que tinham quando entraram. Obrigado!(autor não identificado)

Na disciplina pude ampliar muito a minha visão sobre o assunto, pois me colocou em como eu trataria desse assunto no contexto escolar, e isso foi uma situação totalmente inusitada para mim. Além disso me abriu os olhos para a grande necessidade e importância de abordamos esse assunto dentro das salas de 
aula. Não aprendi só para ensinar para meus futuros alunos, mas aprendi para mim também, por que havia coisas dos orgãos sexuais, sobre DST' e gêneros que eu não sabia ainda. Os temas e textos que trabalhamos me inspiraram de forma que até irei escrever meu TCC nessa área da Ed. Sexual. O método usado pela professora foi muito interessante e legal, de forma que eu aprendi facilmente. Dou parabéns à professora pela iniciativa de criar essa disciplina e ministrá-la com maestria. (autora não identificada).

O uso de cartas é descrito por Buxarrais (1997, apud FIGUEIRO, 2009, p. 160) como “exercícios auto expressivos" que podem ser trabalhados como recurso na Educação Sexual, onde o aluno descreve seus medos, suas angústias, suas dúvidas. Este recurso pode ser utilizado para iniciar o trabalho com a temática, bem como para expressar sua visão de forma reflexiva sobre ela, o que pensam, como foi utilizada para esta pesquisa, e os relatos mostram as percepções dos alunos acerca da disciplina, onde podemos ver nos relatos que novos conhecimentos foram construídos, novas visões sobre a sexualidade, o reconhecimento da importância e a contribuição da disciplina na formação do professor, para este atuar de forma segura em sala de aula, as possibilidades de metodologia para trabalhar a temática, o tempo que acabou sendo insuficiente também foi relatado. O que nos leva a crer que a necessidade de reflexão sobre a temática deve ser contínua, no processo de formação do professor. 


\section{CONSIDERAÇÕES FINAIS}

A presente investigação foi motivada pela necessidade que senti em buscar possibilidades para o ensino da Educação Sexual na formação inicial de licenciados em Ciências Naturais, e por reconhecer a importância de aprimorar a minha prática pedagógica frente ao desafio de abordagem dessa temática no ambiente educacional.

Foi perceptível a necessidade de se trabalhar a temática no contexto da formação inicial, uma vez que os licenciandos demostraram não ter contato com a temática durante o curso. Os resultados mostram que a reflexão é fundamental para o aprimoramento da prática docente, bem como pessoal.

A proposta educativa de uma disciplina contribui para abertura de espaço para discussões e reflexões acerca da Educação Sexual no curso de Ciências Naturais. Os alunos mostraram-se entusiasmados com a possibilidade de aprendizagem sobre a temática, uma vez que foi possível sensibilizá-los com os textos trabalhados e discutidos durante a disciplina. As reflexões apresentadas indicam que é possível uma mudança de postura, quebra de paradigmas, bem como reconhecimento de preconceitos absorvidos pela sociedade em que estão inseridos.

A prática reflexiva e as discussões também puderam levá-los ao desenvolvimento de estratégias e recursos didáticos para trabalhar a temática em sala de aula com segurança e confiança.

De acordo com o que foi apresentado, conclui-se que, mesmo com muitos preconceitos e tabus relacionados à sexualidade é possível trabalhar a Educação Sexual em sala de aula, com atividades que são viáveis e que podem favorecer o ensino da temática, como por exemplo, uso de recursos didáticos, dinâmicas, jogos, entre outros. É importante que haja diálogo, reflexão e, assim sendo, é possível identificar possibilidades e aproveitá-las para promoção do aprendizado, bem como para o enriquecimento pessoal, as trocas são muitos importantes para nosso crescimento e amadurecimento. 


\section{REFERÊNCIAS BIBLIOGRÁFICAS}

ALTMANN, H. Orientação Sexual nos Parâmetros Curriculares Nacionais. Revista Estudos Feministas, p. 575-585, 2001.

BARBATO, S.; MACIEL, D. A. Desenvolvimento humano, educação e inclusão escolar. In: KELMAN, C. A. (Org.) Sociedade Educação e Cultura. Brasília: Editora UnB, 280 p. 2010.

BOGDAN, R.C.; BIKLEN, S. K. Características da Investigação Qualitativa. In. Investigação qualitativa em educação. Uma introdução à teoria e aos métodos. Porto, Portugual: Porto, p. 47$51,1994$.

BRASIL. Secretaria de Educação Fundamental. Parâmetros Curriculares Nacionais : apresentação dos temas transversais, ética / Secretaria de Educação Fundamental. - Brasília : MEC/SEF, 1997,146p.

- Secretaria de Educação Fundamental. Parâmetros Curriculares Nacionais: Ciências Naturais / Secretaria de Educação Fundamental. Brasília : MEC /SEF, 1998, 138p.

_ LEI MARIA DA PENHA. Lei N. ${ }^{\circ} 11.340$, de 7 de Agosto de 2006.

CERTEZA, L. M. A sexualidade da pessoa com deficiência. Anais do I Simpósio Internacional de Estudos sobre a Deficiência - SEDPcD/Diversitas/USP Legal - São Paulo, junho/2013

CHASSOT, A. A Ciência é masculina? É, sim senhora! Contexto e Educação - Editora Unijuí. Ano 19, nº71/72 - Jan/Dez. 2004 - p. 9-28.

CONNELL, R. Políticas da masculinidade. Educação e Realidade. Vol.20 (2), jul./dez. 1995.

CRESWELL, J. W. Projeto de Pesquisa: métodos qualitativo, quantitativo e misto. Tradução Luciana de Oliveira da Rocha. 2. Ed. - Porto Alegre: Artmed, 2007.

DUARTE, R. Entrevistas em pesquisas qualitativas. Editora UFPR. Educar, Curitiba, n. 24, p. 213-225, 2004. Disponível em: http://www.scielo.br/pdf/er/n24/n24a11.pdf. Acesso em: 17 de nov. de 2015.

FIGUEIRO, M. N. D. Educação Sexual e Política de Leiturização: uma junção promissora. Revista. Bras. Est. Pedag. Brasília, v.76, n.184, p.699-734, 1995. 
- Educação Sexual: retomando uma proposta, um desafio. Londrina. Ed. UEL, 1996, 190p.

- Educação sexual : múltiplos temas, compromisso comum. (org.) Educação Sexual: como ensinar no espaço da escola. - Londrina: UEL, 2009. 190p.

- Educação sexual : múltiplos temas, compromisso comum. (In) OLIVEIRA, V. L. B. (org) Sexualidade no contexto contemporâneo: um desafio aos educadores. Londrina: UEL, 2009. 190p.

- Educação sexual : em busca de mudanças. (In) CARVALHO, F. A. (org.) Que saberes sobre sexualidade são esses que (não) dizemos na escola? - Londrina: UEL, 2009. 208p.

FOUCAUlT, M. A História da Sexualidade. A vontade de saber. Tradução de Maria Thereza da Costa Albuquerque e J. A. Guilhon Albuquerque. Editora Graal. Rio de Janeiro, v. 1. 1988.

GDE. Gênero e diversidade na escola: formação de professoras/es em Gênero, Orientação Sexual e Relações Étnico-Raciais. Livro de conteúdo. Versão 2009. - Rio de Janeiro : CEPESC; Brasília : SPM, 266 p. 2009.

JARDIM, D. P.; BRETAS, J. R. S. Orientação sexual na escola: a concepção dos professores de Jandira - SP. Revista Brasileira de Enfermagem, 2006, p.157-62.

LAVILlE, C.; DIONNE, J. A construção do saber: manual de metodologia da pesquisa em ciências humanas. Tradução de Heloísa Monteiro e Francisco Settineri. Porto Alegre: Artmed; Belo Horizonte: Editora UFMG, 1999.

LOURO, G. L. Gênero, sexualidade e educação: uma perspectiva pós-estruturalista. 13.ed. Petropolis, Rio de Janeiro, Editora: Vozes, 2011.

LUDKE, M.; ANDRE, M. E. D. A. Pesquisa em Educação: Abordagens Qualitativas. São Paulo: EPU, 1986.

MAIA, A. C. B.; FARIAS, M. O.; PACINI, B. A.; JUNIOR, L. C. F.; FREITAS, R. M. C. Orientação Sexual para professores: formulário para avaliar a aquisição de conhecimento sobre sexualidade infantil. Mimesis, Bauru, v. 27, n. 2, p. 107-123, 2006. 
MAISTRO, V. I. A.; ARRUDA, S. M.; JUNIOR, A. L. O Papel do Professor em um Projeto de Educação Sexual. VII Enpec. Encontro Nacional de Pesquisa em Educação em Ciências, Florianópolis, 2009.

MOIZÉS, Julieta Seixas; BUENO, Sonia Maria Vilela. Compreensão sobre sexualidade e sexo nas escolas segundo professores do ensino fundamental. Universidade de São Paulo, 2009.

NEVES, J. L.. Pesquisa Qualitativa - Características, Usos e Possibilidades. Caderno de Pesquisas em Administração, São Paulo, V. 1, Nº 3, 2º Sem. 1996.

NÓVOA, A.. Desafios do trabalho do professor no mundo contemporâneo. SINPRO-SP, Edição J.S. Faro e Priscila Gutierre. São Paulo, 2007

- Para uma formação de professores construída dentro da profissão. In: Professores imagens do futuro presente. Educa. Lisboa, Portugual, 2009.

RAMIRO, L.; MATOS, M. G. Percepções de professores portugueses sobre Educação Sexual. Revista Saúde Pública, Lisboa, Portugual, 2008.

REGIMENTO INTERNO DA FACULDADE UNIVERSIDADE DE BRASÍLIA PLANALTINA. (REUNIÃO EXTRAORDINÁRIA DO CONSELHO FUP em 29/10/2014 (430 a Reunião do CONSUNI 27/11/2015). Brasília, Planaltina - DF, 27 de novembro de 2015.

RODRIGUES, A. R. F.; SALLES, G. D. Educação Sexual, Gênero e Diversidade Sexual: Formação de Professoras e Alunas Multiplicadoras como Metodologia de Ensino. Anais II Simpósio Gênero e Políticas Públicas ISSN2177-8248 Universidade Estadual de Londrina, 18 e 19 de agosto de 2011. GT6- Gênero e Educação.

SILVA, L. M. M.; SANTOS, S. P. Sexualidade e Formação Docente: representações de futuros professores/as de Ciências e Biologia. VII Encontro Nacional de Pesquisa em Educação em Ciências, Campinas, 2011.

SILVA, R. C. P.; NETO, J. M. Formação de Professores e Educadores para Abordagem da Educação Sexual na Escola: O que Mostram as Pesquisas. Ciência E Educaçãa, v. 12, n. 2, p. 185197, 2006.

SOUZA, S. E. O uso de recursos didáticos no ensino escolar. I Encontro de Pesquisa em Educação, IV Jornada de Prática de Ensino, XIII Semana de Pedagogia da UEM: "Infância e Práticas Educativas". Arq Mudi. Maringá, PR, 2007;11(Supl.2).

STAKER, H.; HORN, M. B. Classifying K-12 blended learning. Mountain View, CA: Innosight 
Institute, Inc. 2012. Disponível em: <http://www.christenseninstitute.org/wpcontent/uploads/2013/04/Classifying-K-12-blended-learning.pdf>. Acesso em: 15 fev. 2016.

UNIVERSIDADE DE BRASILIA. Projeto Pedagógico do Curso de Segunda Licenciatura em Ciências Naturais. Brasília, dezembro de 2013.

- Disponível em: <https://matriculaweb.unb.br/graduacao/curriculo.aspx?cod=2283> Acesso em 16 Out 2015.

\section{Filme:}

AS SESSÕES. Direção: Bem Lewin. Produção: Judi Levine, Stefhen Nemeth, Bem Lewin. EUA. Fox Searchlight Pictures, 2012. 1 DVD (95min), [Título original: The Sessions]. 


\section{APÊNDICE A}

\section{Termo de Consentimento Livre e Esclarecido (TCLE)}

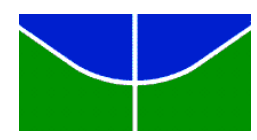

UNIVERSIDADE DE BRASÍLIA

Programa de Pós-Graduação em Ensino de Ciências

Mestrado profissionalizante em Ensino de Ciências

Você está sendo convidado (a) para participar da pesquisa "Educação Sexual e a Formação de Professores de Ciências Naturais: Uma Proposta para Formação Inicial dos Licenciandos em CN da Fup" de responsabilidade de Andrezza Romênia Lima de Abreu, aluna do Programa de PósGraduação em Ensino de Ciências da Universidade de Brasília, sob orientação da Professora Dra. Alice Melo Ribeiro e coorientação da Profa. Dra. Maria de Lourdes Lazzari de Freitas.

A pesquisa tem como objetivo realizar um diagnóstico junto aos licenciandos em Ciências Naturais da Fup quanto ao seu conhecimento e formação sobre a Educação Sexual, e propor uma disciplina para que fomente a formação dos mesmos quanto à temática abordada. A coleta de dados será feita por meio de observações (diário de bordo), rodas de conversas, gravações e análise documental.

Com base nessas informações espera-se uma que a parceria, professores-pesquisadores, propor sugestões e desenvolver atividades que auxiliem na formação dos licenciandos, bem como contribuir para sua pratica docente.

A sua contribuição é muito importante e, em qualquer etapa do estudo, você terá acesso aos pesquisadores para esclarecimento de eventuais dúvidas.

As informações obtidas serão analisadas em conjunto com outros sujeitos da pesquisa, não sendo divulgada a identificação de nenhum participante. Fica assegurado, também, o seu direito às informações sobre os resultados parciais da pesquisa.

Não há despesas pessoais para a sua participação em qualquer fase do estudo, nem tão pouco compensação financeira. Se existir qualquer despesa, ela será absorvida pelo orçamento da pesquisa.

Explicitamos ainda que a execução da pesquisa será utilizada exclusivamente para fins acadêmicos.

É garantida aos sujeitos da pesquisa a liberdade da retirada de consentimento e o abandono do estudo a qualquer momento.

$\mathrm{Eu}$, declaro ter sido informado(a) e concordo em participar, como voluntário(a) da pesquisa acima descrita.

Brasília 2016

Para contato:

Assinatura da Pesquisadora

Andrezza Romênia Lima de Abreu (Mestranda e Pesquisadora), telefone: (61) 9294-7492, e-mail: andrezza_romenia@hotmail.com; Alice Melo Ribeiro (Orientadora e Pesquisadora), telefone: (61) 3107- 2907, e-mail: alice.ribeiro.unb@gmail.com; Maria de Lourdes Lazzari de Freitas (Co-orientadora e Pesquisadora), telefone: (61) 8133-6802, e-mail: mllazzari@gmail.com. 


\section{APÊNDICE B}

\section{Ementa da disciplina}

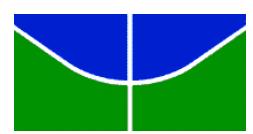

Universidade de Brasília

Faculadade UnB de Planaltina

Disciplina: Tópicos Especiais no Ensino de Ciências (Educação Sexual)

Código: 120090

Dia/Hórario: Terça-feira das 19:00 às 20:40 hs

Carga horária: 30 horas

Professoras Responsáveis: Andrezza Romênia/Maria de Lourdes Lazzari

Contato: andrezza_romenia@hotmail.com; mllazzari@gmail.com

Dia/Horário de atendimento: Terça-feira das 14:00 às 17:00 hs.

Objetivo: Sensibilizar os licenciandos acerca da Educação Sexual, criando um espaço na universidade aberto para reflexão, discussão e aprendizagens sobre essa temática, propor estratégias de ensino para trabalhar a Educação Sexual em sala de aula contribuindo para formação inicial dos mesmos.

Ementa: Educação Sexual, Gênero e diversidade, Homossexualidade, Violência, Abuso Sexual, Anatomia e fisiologia dos órgãos sexuais, Métodos contraceptivos, Gravidez na adolescência, Aborto, DST, Discriminação e preconceito.

\section{CRONOGRAMA DE AULAS - 01/2016}

\begin{tabular}{|c|l|l|}
\hline Data & \multicolumn{1}{|c|}{ Tema } & \multicolumn{1}{c|}{ Bibliografia } \\
\hline $15 / 03$ & Apresentação & Apresentação da disciplina, conhecendo os alunos. \\
\hline $22 / 03$ & $\begin{array}{l}\text { Conhecimentos básicos } \\
\text { sobre Sexualidade }\end{array}$ & $\begin{array}{l}\text { FIGUEIRO, M. N. D. Educação Sexual: retomando } \\
\text { uma proposta, um desafio. Londrina. Ed. UEL, 1996, } \\
\text { 190p. }\end{array}$ \\
\hline $29 / 03$ & Gênero e diversidade & $\begin{array}{l}\text { Gênero e diversidade na escola: formação de } \\
\text { professoras/es em Gênero, Orientação Sexual e } \\
\text { Relações Étnico-Raciais. Livro de conteúdo. Versão } \\
\text { 2009. - Rio de Janeiro : CEPESC; Brasília : SPM, } \\
\text { 2009. }\end{array}$ \\
\hline $05 / 04$ & $\begin{array}{l}\text { Homens, mulheres e a } \\
\text { Ciência }\end{array}$ & $\begin{array}{l}\text { CHASSOT, A. A Ciência é masculina? É, sim } \\
\text { senhora! Contexto e Educação - Editora Unijuí. Ano } \\
19, \text { no71/72 - Jan/Dez. 2004 - p. 9-28. }\end{array}$ \\
\hline $12 / 04$ & Novas Famílias & $\begin{array}{l}\text { Reportagem Famílias Reconstituída, Monoparental e } \\
\text { Homoafetiva. } \\
\text { https://www.youtube.com/watch?v=QoXBRJyxePM }\end{array}$ \\
\hline $19 / 04$ & Roda de Conversa & $\begin{array}{l}\text { Roda de conversa com Prof. Diego Jácome tema: } \\
\text { Educação Sexual em diferentes espaços escolares. }\end{array}$ \\
\hline
\end{tabular}




\begin{tabular}{|c|c|c|}
\hline $26 / 04$ & $\begin{array}{l}\text { Violência e Abuso } \\
\text { Sexual }\end{array}$ & Seminário \\
\hline $03 / 05$ & $\begin{array}{l}\text { Homossexualidade na } \\
\text { escola }\end{array}$ & Seminário \\
\hline $10 / 05$ & $\begin{array}{l}\text { Gravidez na } \\
\text { Adolescência }\end{array}$ & Seminário \\
\hline $17 / 05$ & $\begin{array}{l}\text { Anatomia e fisiologia dos } \\
\text { órgãos sexuais e Métodos } \\
\text { Contraceptivos }\end{array}$ & Seminário \\
\hline $24 / 05$ & $\begin{array}{l}\text { Discriminação } \quad X \\
\text { Solidariedade }\end{array}$ & $\begin{array}{l}\text { BANDEIRA, L.; BATISTA, A. S.. Preconceito e } \\
\text { discriminação como expressões de violência. Instituto } \\
\text { de Estudos de Gênero da Universidade Federal de } \\
\text { Santa Catarina. Estudos Feministas, Vol. 10, No. } 1 \\
\text { (2002), p. 119-141 }\end{array}$ \\
\hline $31 / 05$ & $\begin{array}{l}\text { A sexualidade na } \text { vida } \\
\text { das pessoas } \\
\text { deficiência }\end{array}$ & $\begin{array}{l}\text { AS SESSÕES. Direção: Bem Lewin. Produção: Judi } \\
\text { Levine, Stefhen Nemeth, Bem Lewin. EUA. Fox } \\
\text { Searchlight Pictures, 2012. 1 DVD (95min), [Título } \\
\text { original: The Sessions]. }\end{array}$ \\
\hline $07 / 06$ & Recursos Didáticos & $\begin{array}{l}\text { Professora convidada Samara Anjos da Costa. } \\
\text { Exemplos de recursos didáticos sobre Sexualidade. }\end{array}$ \\
\hline $14 / 06$ & Roda de Conversa & $\begin{array}{l}\text { Roda de conversa com Enfermeira Regina PS1 } \\
\text { Planaltina, tema: DST. }\end{array}$ \\
\hline $21 / 06$ & Aula Livre & Elaboração da atividade final. \\
\hline $28 / 06$ & Atividade final & $\begin{array}{l}\text { Apresentação da atividade com elaboração de recurso } \\
\text { didático }\end{array}$ \\
\hline $05 / 07$ & & Divulgação das menções \\
\hline
\end{tabular}

\section{Parâmetros de Avaliacão:}

20\% Participação - Durante as aulas, discussões após as apresentações dos textos, roda de conversa e Moodle (Relatórios).

$30 \%$ Seminários - Em grupo, parte escrita e exposição oral.

$50 \%$ Atividade final - Em grupo, exposição oral 25\% e parte escrita postada no Moodle $25 \%$.

\section{Lembrete:}

- Para aprovação o aluno deverá ter cumprido todas as atividades propostas e ter $75 \%$ de presença nas aulas.

- O presente plano de ensino está sujeito a mudanças, mediante aviso prévio do professor aos estudantes. 


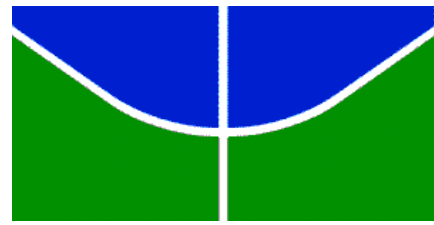

UNIVERSIDADE DE BRASÍLIA - UnB

Instituto de Ciências Biológicas

Instituto de Física

Instituto de Química

Faculdade UnB Planaltina

Programa de Pós-Graduação em Ensino de Ciências

Mestrado Profissional em Ensino de Ciências

\section{EDUCAÇÃO SEXUAL}

ANDREZZA ROMENIA LIMA DE ABREU

Proposta de ação profissional resultante da dissertação realizada sob a orientação da Prof $^{a}$. Dr ${ }^{a}$. Alice Melo Ribeiro e coorientação da Prof. $^{\text {a }}$ Dr. ${ }^{\text {a }}$ Maria de Lourdes Lazzari de Freitas e apresentada à banca examinadora como requisito parcial à obtenção do Título de Mestre em Ensino de Ciências, pelo Programa de Pós-Graduação em Ensino de Ciências da Universidade de Brasília. 


\section{Apresentação}

Essa proposição didática é parte integrante da dissertação de Mestrado intitulada "Educação Sexual e a formação de Professores: uma proposta para formação inicial dos licenciandos em Ciências Naturais” do Programa de Pós-Graduação em Ensino de Ciências-UnB.

Ao concluir a graduação, sempre visei dar continuidade à minha formação profissional, foi então que surgiu uma oportunidade de desenvolvimento e aprendizagem pessoal e profissional no PPGEC. Ingressei no PPGEC em 2015 e participei de disciplinas que fortaleceram e aprimoraram meus conhecimentos. Com a minha trajetória acadêmica, senti a necessidade de trabalhar o tema Educação Sexual na perspectiva de colaborar com a formação inicial dos licenciandos em Ciências Naturais, proporcionando uma reflexão sobre a temática e buscando possibilidades e estratégias para o ensino em sala de aula.

A presente proposta apresenta um material de apoio para a utilização da temática Educação Sexual em uma disciplina para Formação Inicial de licenciandos em Ciências Naturais, bem como, cabendo também para qualquer outra licenciatura, ou até mesmo para criação de projetos de pesquisa. Não limitando-se apenas a disciplinas. Apresentarei a seguir algumas considerações sobre a Sexualidade, Educação Sexual e a Escola, e a formação de professores apoiando-me em Foucault (1988), Figueiró (1996, 2009) e Nóvoa (2007). Em seguida trazemos algumas sugestões de leitura e recursos didáticos para abordagem da temática. 


\section{Contextualizando}

A história da sexualidade segundo Foucault (1988) começa a ser discutida cientificamente por profissionais da medicina durante o século XIX, onde a medicina passa a estudar o sexo, seguindo o modelo até então utilizado pela Igreja: a confissão/pecado. Assim surge a "Scientia Sexualis" (Ciência Sexual) conceituada por Foucault como o corpo de conhecimento o qual foi construído por dados coletados pelos médicos da época. Figueiró (1996) baseada na obra de Foucault destaca a importância de esclarecer que os discursos coletados dos pacientes eram justamente pautados em "aberrações, perversões, extravagancias excepcionais, enfim, em sexualidades periféricas" (p.62). Assim muitos aspectos da sexualidade foram encarados como doença (medicalização do sexo), essa pratica médica, com política de higiene, passou a exercer um controle sobre a vida social e sexual das pessoas, propondo-se a assegurar o vigor físico e a pureza moral.

Nos seus estudos Foucault trouxe uma visão ao conceito de sexualidade, com um olhar diferenciado, não mais higienista, biológico, e sim num aspecto histórico-cultural e politico.

Segundo Silva e Santos (2011), historicamente a comunidade escolar vem delegando aos professores de Biologia e Ciências a responsabilidade de orientação e conteúdo sobre a o tema Educação Sexual. Infelizmente tal prática ou discussão ainda não ocorrem de maneira natural e sistemática, entendida como parte das várias dimensões do ser humano.

Os Parâmetros Curriculares Nacionais ( $\mathrm{PCN})$ propõem que os temas sobre sexualidade sejam apresentados por meio da transversalidade dos conteúdos na escola. O conhecimento do corpo transcende sua dimensão biológica. No corpo estão inscritas a história de vida, a cultura, os desejos e as aprendizagens do indivíduo (BRASIL, 1998).

Para Figueiró (1996), a Educação Sexual é “toda ação de ensino-aprendizagem sobre a sexualidade humana, seja a nível de conhecimento de informações básicas, seja a nível de conhecimento e/ou discussões e reflexões sobre valores, normas, sentimentos, emoções e atitudes relacionadas à vida sexual” (p. 17).

Figueiró (1995) afirma que temas relacionados à Educação Sexual são ricos, no sentido de abrir caminhos para o desenvolvimento da criticidade dos alunos e para conquista da democracia. A autora aborda que, além de se tratar essa temática da sexualidade na escola, o/a aluno(a) deve ser ensinado(a)/estimulado(a) quanto à leitura para que se torne um auto educando(a).

A Educação Sexual e a formação do leitor são, pois, mutuamente complementares, uma vez que, aproveitando a temática sexualidade, que é um assunto mobilizador (de interesse e curiosidade de pessoas das variadas idades), pode-se, usando os 
livros de Educação Sexual, levar o sujeito a desenvolver o gosto e o hábito da leitura. Em contrapartida, isso reforça a Educação Sexual, podendo constituir-se numa eficaz estratégia que auxilie a suprir a necessidade, já discutida, de levar os educandos a terem repetidas oportunidades de rever, integrar e ampliar seus conhecimentos sobre sexualidade (FIGUEIRÓ, 1995, p.721).

Ramiro e Matos (2008) destacam que a escola é lugar privilegiado para realização da educação sexual, formal e articulada, pois crianças e adolescentes permanecem um tempo significativo na escola.

Silva e Santos (2011) verificaram em seus estudos que existe uma lacuna na formação inicial do docente, pois no currículo regular do curso de licenciatura não existe um espaço para a reflexão com os futuros professores sobre a sexualidade, dificultando trabalhos teóricos e práticos cientificamente fundamentados. Neste sentido Nóvoa (2007) afirma que um bom/oa professor/a busca novas estratégias e possibilidades de ensino e aprendizagem, consegue fazer a diferença em prol da educação.

A Educação Sexual vem sendo reconhecida pela maioria dos professores como necessária e importante no processo formativo dos alunos. Figueiró (2009) afirma que todos educamos sexualmente nossos alunos, mesmo que não tenhamos consciência, por meio da forma como lidamos com as situações do dia a dia. Nóvoa (2009) explicita que "ensinamos aquilo que somos e que, naquilo que somos, se encontra muito daquilo que ensinamos" (p.15). Com a nossa postura, contribuímos para que o aluno forme uma imagem positiva ou negativa do corpo, da sexualidade e do relacionamento sexual.

Uma forma de se trabalhar essa temática em sala de aula é com a utilização de recursos, o conceito de recursos didáticos segundo Souza (2007) são todos os recursos que visam auxiliar o educando a realizar sua aprendizagem mais eficientemente, constituindo-se num meio para facilitar, incentivar ou possibilitar o processo ensino-aprendizagem. O material didático é um instrumento de trabalho na sala de aula: informa, cria, induz à reflexão, desperta outros interesses, motiva, sintetiza conhecimentos e propicia vivências culturais, sua aplicabilidade enriquece a prática docente (BRASIL, 1998, p.79).

Nas tabelas abaixo apresento algumas temáticas e como podem ser trabalhadas, e algumas sugestões de referências e recursos didáticos que podem ser utilizados.

Tabela 1: Sugestões de temas e bibliografias para aula de Educação Sexual

\begin{tabular}{|l|l|}
\hline \multicolumn{1}{|c|}{ TEMAS } & \multicolumn{1}{c|}{ SUGESTÕES BIBLIOGRAFICAS } \\
\hline Sexualidade - Conhecimentos básicos & $\begin{array}{l}\text { FIGUEIRO, M. N. D. Educação Sexual: } \\
\text { retomando uma proposta, um desafio. } .\end{array}$ \\
\hline
\end{tabular}




\begin{tabular}{|c|c|}
\hline & Londrina. Ed. UEL, 1996, 190p. \\
\hline Gênero e diversidade & $\begin{array}{l}\text { Gênero e diversidade na escola: formação de } \\
\text { professoras/es em Gênero, Orientação Sexual } \\
\text { e Relações Étnico-Raciais. Livro de conteúdo. } \\
\text { Versão 2009. - Rio de Janeiro : CEPESC; } \\
\text { Brasília : SPM, 2009. }\end{array}$ \\
\hline Violência e abuso sexual & $\begin{array}{l}\text { ELSEN, I.; PROSPERO, E. N. S.; } \\
\text { SANCHES, E. N.; FLORIANO, C. J.; } \\
\text { SGROTT, B. C.. Escola: um espaço de } \\
\text { revelação da violência doméstica contra } \\
\text { crianças e adolescentes. Psicol. Argum. } 2011 \\
\text { jul./set., 29(66), 303-314 }\end{array}$ \\
\hline Preconceito e discriminação & $\begin{array}{l}\text { BANDEIRA, L.; BATISTA, A. S.. } \\
\text { Preconceito e discriminação como expressões } \\
\text { de violência. Instituto de Estudos de Gênero } \\
\text { da Universidade Federal de Santa Catarina. } \\
\text { Estudos Feministas, Vol. 10, No. } 1 \text { (2002), p. } \\
\text { 119-141 }\end{array}$ \\
\hline $\begin{array}{l}\text { Gravidez na adolescência e Métodos } \\
\text { contraceptivos }\end{array}$ & $\begin{array}{l}\text { MOREIRA, T. M. M.; VIANA, D. S.; } \\
\text { QUEIROZ, M. V. O.; JORGE, M. S. B. J.. } \\
\text { Conflitos vivenciados pelas adolescentes com } \\
\text { a descoberta da gravidez. Rev. Esc. Enferm } \\
\text { USP 2008; 42(2):312-20. }\end{array}$ \\
\hline $\begin{array}{l}\text { A Sexualidade na vida das pessoas com } \\
\text { deficiências. }\end{array}$ & $\begin{array}{l}\text { Filme “As Sessões” Direção: Bem Lewin. } \\
\text { Produção: Judi Levine, Stefhen Nemeth, Bem } \\
\text { Lewin. EUA. Fox Searchlight Pictures, } 2012 . \\
1 \text { DVD (95min), [Título original: The } \\
\text { Sessions]. }\end{array}$ \\
\hline
\end{tabular}

Tabela 2: Sugestões de recursos didático e sua descrição.

\begin{tabular}{|l|l|}
\hline \multicolumn{1}{|c|}{ ATIVIDADE } & \multicolumn{1}{c|}{ DESCRIÇão } \\
\hline Semáforo & Exposição de dúvidas acerca do tema. \\
\hline
\end{tabular}




\begin{tabular}{|c|c|}
\hline Vocábulos & $\begin{array}{l}\text { Palavras e conceitos inerentes aos temas } \\
\text { abordados }\end{array}$ \\
\hline Transformações biológicas e psicológicas & $\begin{array}{l}\text { Identificação das principais mudanças no } \\
\text { corpo pós puberdade e durante a fase da } \\
\text { adolescência }\end{array}$ \\
\hline Desenvolvendo a responsabilidade & $\begin{array}{l}\text { Os alunos deverão ter o máximo de cuidado } \\
\text { com o ovo (mascote), durante as três semanas } \\
\text { não poderão deixá-lo na chuva ou exposto ao } \\
\text { sol, bem como quebrá-lo. Eles deverão } \\
\text { assumir a responsabilidade de cuidar e } \\
\text { proteger o mascote como se fosse uma } \\
\text { criança. }\end{array}$ \\
\hline Aspectos socioculturais da sexualidade & $\begin{array}{l}\text { As relações existentes, diferenças entre ficar e } \\
\text { namorar. Discussão de temas como "Ficar é o } \\
\text { começo para namorar", "Todos os namorados } \\
\text { transam". Vamos tratar ainda de temas como } \\
\text { meu primeiro amor, primeiro beijo, as células } \\
\text { que movimentam o corpo durante o beijo e } \\
\text { quando o sentimento "gostar" começa a ficar } \\
\text { evidente. }\end{array}$ \\
\hline Mito x verdade & Afirmativas expostas para julgamento. \\
\hline Gravidez/metódos contraceptivos/DST's - & $\begin{array}{l}\text { Modelos anatômicos dos períodos de } \\
\text { gestação. Painel ilustrativo com métodos } \\
\text { contraceptivos e Informativos/folderes da } \\
\text { ecretaria de saúde. }\end{array}$ \\
\hline Situações Problemas & $\begin{array}{l}\text { Organizadas de acordo com a faixa etária dos } \\
\text { estudantes e aplicada adotando-se a dinâmica } \\
\text { da batata quente. }\end{array}$ \\
\hline
\end{tabular}


As tabelas apresentadas acima trazem alguns conteúdos com referências bibliográficas que podem ser utilizadas para trabalhar com a Educação Sexual. Os temas e alguns recursos apresentados foram trabalhadas na disciplina abordada neste trabalho para formação inicial de licenciandos em $\mathrm{CN}$. As sugestões apresentadas podem ser utilizadas em uma disciplina, ou em projetos de extensão. Os recursos didáticos podem ser adaptados para os conteúdos e público alvo que se deseja atingir. Figueiró (2009) em seu livro Educação Sexual: Múltiplos temas, compromisso comum, tem um capitulo intitulado: Educação Sexual: como ensinar no espaço da escola, onde a autora traz muitas contribuições para o ensino da temática na escola, sua referência pode ser encontrada nas referências deste trabalho. É uma excelente sugestão de leitura para temática.

Outra forma de abordagem da temática da Educação Sexual pode ser feita por meio de rodas de conversas, onde a troca de informações, experiências, dúvidas e conhecimentos entre os participantes propicia o ensino aprendizagem dos envolvidos. Esperamos que a proposta possa ajudá-los durante a prática docente. 


\section{Referências Bibliográficas}

BRASIL. Secretaria de Educação Fundamental. Parâmetros Curriculares Nacionais : Ciências Naturais / Secretaria de Educação Fundamental. . Brasília : MEC /SEF, 1998.

FIGUEIRO, M. N. D. Educação sexual : múltiplos temas, compromisso comum. (org.) Educação Sexual: como ensinar no espaço da escola. - Londrina: UEL, 2009. 190p.

- Educação sexual : múltiplos temas, compromisso comum. (In) CARVALHO, F. A. (org.) Que saberes sobre sexualidade são esses que (não) dizemos na escola? - Londrina: UEL, 2009. 190p.

- Educação Sexual: retomando uma proposta, um desafio. Londrina. Ed. UEL, 1996, 190p.

- Educação Sexual e Política de Leiturização: uma junção promissora. Revista. Bras. Est. Pedag. Brasília, v.76, n.184, p.699-734, 1995.

NÓVOA, A.. Desafios do trabalho do professor no mundo contemporâneo. SINPRO-SP, Edição J.S. Faro e Priscila Gutierre. São Paulo, 2007.

- Para uma formação de professores construída dentro da profissão. In: Professores imagens do futuro presente. Educa. Lisboa, Portugual, 2009.

RAMIRO, L.; MATOS, M. G. Percepções de professores portugueses sobre Educação Sexual. Revista Saúde Pública, Lisboa, Portugual, 2008.

SILVA, L. M. M.; SANTOS, S. P. Sexualidade e Formação Docente: representações de futuros professores/as de Ciências e Biologia. VII Encontro Nacional de Pesquisa em Educação em Ciências, Campinas, 2011

SOUZA, S. E. O uso de recursos didáticos no ensino escolar. I Encontro de Pesquisa em Educação, IV Jornada de Prática de Ensino, XIII Semana de Pedagogia da UEM: "Infância e Práticas Educativas". Arq Mudi. Maringá, PR, 2007;11(Supl.2). 
